\title{
GENETIC FACTORS IN GENERALIZED OSTEO-ARTHROSIS
}

\author{
BY \\ J. H. KELLGREN, J. S. LAWRENCE, AND FRIDA BIER \\ From the Rheumatism Research Centre and the Empire Rheumatism Council Field Unit, \\ University of Manchester
}

The occurrence of osteo-arthrosis in multiple joints was noted by Adams (1857). Cecil and Archer (1926) observed that the condition was more often polyarticular than monarticular in patients attending their rheumatism clinic, occurred mainly in middle-aged females, and was usually associated with Heberden's nodes; they labelled the condition menopausal arthritis. Stecher $(1941,1955)$ investigated the families of 64 patients with Heberden's nodes, and found the condition twice as frequently in the mothers and three times as frequently in the sisters of affected women as in the general population. He postulated that the nodes were inherited as a Mendelian dominant in females and as a recessive in males. It was apparent from his findings that arthrosis of the distal interphalangeal joints of the fingers had a hereditary basis. Although the proximal interphalangeal joints of the fingers were involved in 25 per cent. of Stecher's cases, he did not find clinical evidence of any association with osteo-arthrosis of other joints. Kellgren and Moore (1952), on the other hand, from a study of 391 patients with osteo-arthrosis attending a rheumatism clinic, found evidence of an association of Heberden's nodes with a distinct pattern of joint involvement, including the first carpometacarpals. the proximal interphalangeals, the apophyseal joints of the spine, the knees, and the first tarsometatarsals. This association of Heberden's nodes with multiple osteo-arthrosis was later confirmed by $x$-ray studies on a random sample of the population of Leigh, Lancs., and the characteristic pattern of joint involvement was corroborated (Kellgren and Lawrence, 1958). Whilst indirect evidence of a hereditary basis for a generalized form of osteo-arthrosis was thus forthcoming, it was felt that this should be confirmed by a direct approach and that steps should be taken to discover whether the mode of inheritance postulated by Stecher for Heberden's nodes also applied to this generalized form of osteoarthrosis.

In addition, it was felt that other forms of multiple osteo-arthrosis of varying aetiology might exist, some associated with occupation, others with a genetic factor. Certain rare forms are already known to occur, for example the type associated with ochronosis, and the multiple osteo-arthrosis associated with gout may well be more frequent than is generally supposed. Rheumatoid arthritis has also been postulated as a cause of osteo-arthrosis. An inherited tendency to multiple osteo-arthrosis is also known to exist in certain strains of laboratory animals and these have been studied extensively (Silberberg and Silberberg, 1955; Sokoloff, Mickelsen, Silverstein, Jay, and Yamamoto, 1960; Sokoloff, Crittenden, Yamamoto, and Jay, 1962).

\section{Method}

For this study probands were chosen from random samples of the population of the town of Leigh in Lancashire, obtained during surveys in 1954 and 1956-59, and from a sample of the population of Wensleydale in Yorkshire, surveyed in 1958-59. The methods of sampling in Leigh and Wensleydale have already been described (Kellgren and Lawrence, 1956; Lawrence and Bennett, 1960; Bremner, 1961). $X$ rays were taken of the hands, feet, knees, pelvis, and cervical and lumbar spine-the pelvis being omitted in those under 55 and the lumbar spine and knees in those under 35 years of age. When the $x$ rays were read, the joints were divided into groups and a grading for osteo-arthrosis was given to each group based on the worst affected joint. Thus the ten distal interphalangeal joints of the hands were considered as one group and all the apophyseal joints of the cervical spine as another. In this way 
the joints $x$ rayed were divided into thirteen groups. The probands chosen were those persons aged under 65 in the population samples in Leigh and Wensleydale who had definite radiological evidence of osteo-arthrosis in six or more groups of joints and had first-degree relatives living within defined areas in Lancashire and Yorkshire. The number of six affected joints was chosen as indicating a definite generalization of the pathological process. (It was considered preferable to define the probands in this way rather than to use a grading for generalized osteo-arthrosis which is more difficult to classify.) Disk degeneration was not included in assessing osteo-arthrosis of the spine. Possible probands aged 65 and over were excluded because of the high proportion with multiple osteo-arthrosis in this age group, and because it was felt that the main influence of a genetic factor, if it existed, would be to induce an earlier onset of osteo-arthrosis. Without the qualification of accessible relatives, the total number of probands available according to our criteria amounted to $62: 25$ males and 37 females. Those with relatives who could be examined numbered $52: 20$ males and 32 females.

Heberden's nodes were observed during clinical examination in seven of the twenty males and 25 of the 32 females (Table I). As osteo-arthrosis rarely develops before the fifth decade, Table I also shows separately the probands with relatives aged 45 and over. The grouping by clinicallyobserved Heberden's nodes and by spread and severity of osteo-arthrosis observed on radiographs shows that the disease tended to be more severe in the probands with nodes (referred to hereafter as "nodal"). As indicated, four of the thirteen male probands without nodes (referred to hereafter as "non-nodal") suffered at the same time from inflammatory polyarthritis. This may be compared with 3 per cent. in the Leigh random population sample aged 55-64 (Kellgren and Lawrence, 1956); the difference is statistically significant at the 1 per cent. level. No excess of this feature was found in the other probands. One of the male "non-nodal" probands with inflammatory polyarthritis was also suffering from a moderate degree of psoriasis and one of his offspring showed doubtful signs of the disease; we are not certain whether some minor manifestations of psoriasis may not have escaped observation as the relevant clinical question was not routinely asked at the time. There were nine miners among the thirteen male non-nodal probands (69 per cent.) and four cotton workers among the seven male nodal probands ( 59 per cent.), compared with expected percentages of 40 and 10 respectively. This suggests that the occupational factor may have played a part in the early onset of multiple osteoarthrosis in the male probands. The occupational distribution of the female probands does not markedly differ from expectation: the majority were housewives and the next most frequent occupation was work in the cotton mills, irrespective of whether the probands were nodal or non-nodal. Except for

TABLE I

PROBANDS GROUPED BY PRESENCE AND ABSENCE OF CLINICAL HEBERDEN'S NODES AND SPREAD AND SEVERITY OF RADIOLOGICAL OSTEO-ARTHROSIS

(Numbers added in brackets indicate sufferers from inflammatory polyarthritis contained in the main numbers)

\begin{tabular}{|c|c|c|c|c|c|c|c|c|}
\hline \multirow{3}{*}{ Probands } & \multirow{2}{*}{\multicolumn{2}{|c|}{$\begin{array}{c}\text { Radiological } \\
\text { Osteo-arthrosis } \\
\text { in Probands }\end{array}$}} & \multicolumn{6}{|c|}{ Grade of Clinical Heberden's Nodes in Probands } \\
\hline & & & \multicolumn{3}{|c|}{ Male } & \multicolumn{3}{|c|}{ Female } \\
\hline & Grade & $\begin{array}{l}\text { No. of } \\
\text { Joint Groups } \\
\text { Affected }\end{array}$ & $\begin{array}{c}0-1 \\
\text { (non-nodal) }\end{array}$ & $\underset{\text { (nodal) }}{2-4}$ & Total & $\begin{array}{c}0-1 \\
\text { (non-nodal) }\end{array}$ & $\stackrel{2-4}{\text { (nodal) }}$ & Total \\
\hline \multirow[t]{2}{*}{ All } & \multirow[t]{2}{*}{$2-4$} & $\begin{array}{l}6 \\
7 \\
8 \\
9+ \\
\end{array}$ & $\begin{array}{l}4(2) \\
4(1) \\
3 \\
2(1) \\
\end{array}$ & $\begin{array}{l}1 \\
1 \\
2 \\
3 \\
\end{array}$ & $\begin{array}{l}5 \\
5 \\
5 \\
5 \\
\end{array}$ & $\begin{array}{ll}2(1) \\
1 \\
1 \\
3 \\
\end{array}$ & $\begin{array}{l}9(1) \\
6 \\
7 \\
3 \\
\end{array}$ & $\begin{array}{r}11 \\
7 \\
8 \\
6 \\
\end{array}$ \\
\hline & & Total & $13(4)$ & 7 & 20 & $7(1)$ & $25(1)$ & 32 \\
\hline \multirow{4}{*}{$\begin{array}{c}\text { With } \\
\text { Relatives } \\
\text { aged 45+ } \\
\text { Examined }\end{array}$} & \multirow[t]{2}{*}{$2-4$} & $\begin{array}{l}6 \\
7 \\
8 \\
9+ \\
\end{array}$ & $\begin{array}{l}3(1) \\
4(1) \\
2(1) \\
2(1) \\
\end{array}$ & $\begin{array}{l}1 \\
1 \\
1 \\
3 \\
\end{array}$ & $\begin{array}{l}4 \\
5 \\
3 \\
5 \\
\end{array}$ & $\begin{array}{l}1 \\
1 \\
1 \\
2\end{array}$ & $\begin{array}{l}7(1) \\
4 \\
6 \\
2 \\
\end{array}$ & $\begin{array}{l}8 \\
5 \\
7 \\
4 \\
\end{array}$ \\
\hline & & Total & $11(3)$ & 6 & 17 & 5 & $19(1)$ & 24 \\
\hline & \multirow[t]{2}{*}{$3-4$} & $\begin{array}{l}0-2 \\
3-4 \\
5+\end{array}$ & $\begin{array}{r}4(1) \\
7(2) \\
- \\
\end{array}$ & $\begin{array}{l}2 \\
2 \\
2\end{array}$ & $\begin{array}{l}6 \\
9 \\
2\end{array}$ & $\begin{array}{r}4 \\
1 \\
-\end{array}$ & $\begin{array}{l}5 \\
8(1) \\
6\end{array}$ & $\begin{array}{l}9 \\
9 \\
6\end{array}$ \\
\hline & & Total & $11(3)$ & 6 & 17 & 5 & $19(1)$ & 24 \\
\hline
\end{tabular}


two females in the 45- to 54-year group, all the probands were aged 55-64, which is not surprising considering the stringency of the criteria.

All parents, siblings, and children aged 15 and over of these 52 probands who were living within 10 miles of the $x$-ray centre in Leigh or within 15 miles of the centres used in Wensleydale were visited, and appointments were made for them to attend the centre, or if this was not possible, to be $x$-rayed at home. In this way 183 relatives $(85$ males and 98 females) were brought into the surveya completion rate of 88 per cent. (Table II, below).

The clinical and radiological examinations have been described in an earlier paper (Lawrence and Ball, 1958) and were identical with those used in the random samples in Leigh and Wensleydale. The rheumatoid and osteo-arthrosis family studies were for the most part run concurrently with the examination of random samples of households in the area, and they were so arranged that the assessors were not aware of the disease of the proband when examining the relatives.

Since over two-thirds of the probands and ninetenths of the relatives lived in Leigh, the Leigh random sample only was used as a control.* There were in fact no significant differences between Leigh and Wensleydale as regards the number of joints affected by osteo-arthrosis. The amount of erosive arthritis was almost identical in these two surveys, but clinical inflammatory polyarthritis was recorded as slightly more frequent in the Wensleydale males and clinical Heberden's nodes as slightly more frequent in the Wensleydale females. The sheep cell agglutination test was more often positive in Leigh. The observer whose readings have been used throughout this study read the Wensleydale $x$ rays at other times than those of the Leigh random sample and family study, and the clinical examination was done somewhat later. However, a second observer who read the $x$ rays of both random surveys mixed came to essentially the same conclusions. As regards the clinical findings, intraobserver difference over time cannot be excluded.

Gradings for osteo-arthrosis vary between different observers, and the same observer does not always

* The controls included the whole of the 1954 and 1956-59 surveys, plus a further twenty males and thirty females over 65 years of age examined at the time but not included in previous reports. In Tables III and IV, however, only that half of the 1954 sample which constituted the 55- to 64-year age group in the 1956-59 survey was used, since the remainder were not read for multiple osteo-arthrosis in the simultaneous mixed $x$-ray readings of random samples and relatives which have been used in this study. grade an $x$ ray identically on successive occasions. The probands were selected on the basis of previous $x$-ray readings in which the gradings recorded were not necessarily the same as those recorded when the films were re-read in this study as part of the random sample. To make allowance for such variations, more stringent criteria were applied to the selection of probands than were subsequently used to establish the diagnosis of multiple osteo-arthrosis, and there is little likelihood that any probands have been selected who would in the later readings have fallen below the gradings for multiple osteo-arthrosis recorded in this paper.

The further statistical procedure employed was as follows: For each sex-age group of the Leigh random sample, rates per 100 of the population with $1+, 3+$, and $5+$ joints affected by osteoarthrosis were calculated to obtain the rates expected had the relatives in this study experienced osteoarthrosis at the same rates as the general population of Leigh (Table III, below). As the age distributions in the random sample and the relatives differed, the expected rates for the broader divisions in Table III were calculated as mean rates weighted according to the age distribution in the relatives. The same method was applied to obtain the expected rates in relation to other factors studied in subsequent Tables. These Tables should be read together with the appended Table A, which shows the age distribution by decades of the relatives of the probands in various categories. Although still further detail is not given, it will be readily understood that any difference that did exist between observed and expected rates in the characteristics considered were generally more pronounced in the higher age groups. Not to over-estimate the significance of the differences between observed and weighted expected rates, it was decided that when the weighted expected rates were translated into numbers they should be applied to not more than 70 per cent. of the population sample from which the individual rates on which they are based were derived.* The random sample would not have been large enough to treat the expected as absolute rates with negligible margins of error, particularly as some of its rates were very low. Readers who have dealt with similar problems may not be surprised to learn that, on applying the usual less laborious significance tests to our data, the results did not always appear sufficiently reliable. The available Tables on the binomial distribution

\footnotetext{
* For technical considerations this had to be cut further in part of the final tests so as to limit the combined total of the family and of the final tests so as to
random samples to 400 .
} 
(Mainland, Herrera, and Sutcliffe, 1956; Diem, 1962) gave valuable guidance, and the authors regard themselves fortunate in having been able finally to enlist the help of Mr. D. Downham, who calculated all the probability values in this paper by Fisher's exact test for the 4-fold table, using his own programme on the Atlas computer (Downham and McKay-in preparation). As customary, $P<0.05$ has been accepted as the minimal level of significance.

\section{Completeness of Survey}

It was found that the 52 probands had 209 relatives ( 94 males and 115 females) living in the area (Table II). Only 26 refused both $X$ rays and blood test, so that the completion rate was 88 per cent. Of the 183 who were examined, two refused $X$ ray and have been omitted from the analyses, and eleven had no blood test. Of the 1,864 persons in the random sample, 280 refused both $X$ rays and blood test, so that this survey was 85 per cent. complete, but of the 1,584 persons examined, 33 refused $X$ ray and 93 had no blood test.

TABLE II

COMPLETENESS OF SURVEY

\begin{tabular}{|c|c|c|c|c|c|c|c|c|}
\hline \multirow[b]{2}{*}{ Sample } & \multirow[b]{2}{*}{ Sex } & \multirow{2}{*}{$\begin{array}{c}\text { Total } \\
\text { in } \\
\text { Sample }\end{array}$} & \multirow{2}{*}{$\begin{array}{l}\text { Not Available } \\
\text { or Refused All } \\
\text { Examination }\end{array}$} & \multicolumn{2}{|c|}{ Total Examined } & \multicolumn{3}{|c|}{ Examination } \\
\hline & & & & No. & Per cent. & $\begin{array}{l}\text { Clinical, } \\
X \text { ray, and } \\
\text { Blood Test }\end{array}$ & $\begin{array}{l}\text { Clinical } \\
\text { and } X \text { ray } \\
\text { Only }\end{array}$ & $\begin{array}{l}\text { Clinical and } \\
\text { Blood Test } \\
\text { Only }\end{array}$ \\
\hline \multirow{2}{*}{$\begin{array}{l}\text { Relatives of Osteo- } \\
\text { arthrosis Probands }\end{array}$} & $\begin{array}{ll}\text { Male } & \ldots \\
\text { Female } & \ldots\end{array}$ & $\begin{array}{r}94 \\
115\end{array}$ & $\begin{array}{r}9 \\
17\end{array}$ & $\begin{array}{l}85 \\
98\end{array}$ & $\begin{array}{l}90 \\
85\end{array}$ & $\begin{array}{l}80 \\
90\end{array}$ & $\begin{array}{l}4 \\
7\end{array}$ & $\begin{array}{l}1 \\
1\end{array}$ \\
\hline & Total & 209 & 26 & 183 & 88 & 170 & 11 & 2 \\
\hline \multirow{2}{*}{$\begin{array}{l}\text { Control: Leigh } \\
\text { Random Population }\end{array}$} & $\begin{array}{ll}\text { Male } & \ldots \\
\text { Female } & \ldots\end{array}$ & $\begin{array}{l}876 \\
988\end{array}$ & $\begin{array}{l}115 \\
165\end{array}$ & $\begin{array}{l}761 \\
823\end{array}$ & $\begin{array}{l}87 \\
85\end{array}$ & $\begin{array}{l}717 \\
741\end{array}$ & $\begin{array}{l}30 \\
63\end{array}$ & $\begin{array}{l}14 \\
19\end{array}$ \\
\hline & Total & 1,864 & 280 & 1,584 & 85 & 1,458 & 93 & 33 \\
\hline
\end{tabular}

Note: The 761 males and 823 females examined in the Leigh surveys used as a control comprise the following:

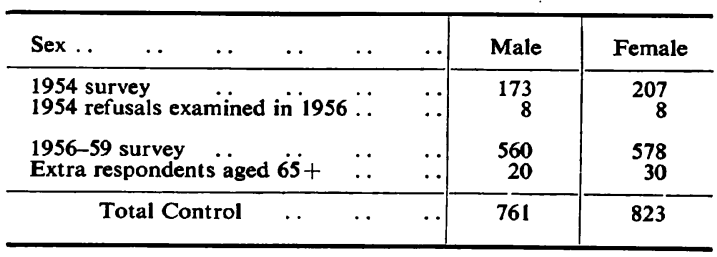

RADIOLOGICAL MULTIPLE OSTEO-ARTHROSIS OF AT

\begin{tabular}{|c|c|c|c|c|c|c|c|c|c|c|c|}
\hline \multirow[t]{2}{*}{ Sex of Relatives } & \multirow[t]{2}{*}{$\begin{array}{lll}. & \cdots & \end{array}$} & \multicolumn{10}{|c|}{ Male } \\
\hline & & \multicolumn{7}{|c|}{ Number } & \multicolumn{3}{|c|}{ Per cent. } \\
\hline \multirow{2}{*}{\multicolumn{2}{|c|}{$\begin{array}{l}\text { Number of Joint Groups with Radiological Osteo- } \\
\text { arthrosis (Grades } 2-4 \text { ) in Relatives }\end{array}$}} & \multirow[t]{2}{*}{0} & \multirow{2}{*}{$1-2$} & \multirow{2}{*}{$3-4$} & \multirow{2}{*}{$5-6$} & \multirow{2}{*}{$7-8$} & \multirow{2}{*}{$9+$} & \multirow{2}{*}{ Total } & \multicolumn{2}{|c|}{$1+$} & \\
\hline & & & & & & & & & Obs. & Exp. & \\
\hline \multirow{5}{*}{$\begin{array}{c}\text { Age Group } \\
\text { of Relatives } \\
\text { (yrs) }\end{array}$} & $\begin{array}{l}15-24 \\
25-34 \\
35-44\end{array}$ & $\begin{array}{r}6 \\
15 \\
9\end{array}$ & $\overline{2}$ & $=$ & 二 & 二 & $=$ & $\begin{array}{r}6 \\
17 \\
16\end{array}$ & $\begin{array}{l}\overline{12} \\
44 \\
\end{array}$ & $\begin{array}{r}8 \\
15 \\
37\end{array}$ & $\bar{z}$ \\
\hline & Total $15-44$ & 30 & 9 & - & - & - & - & 39 & 23 & 23 & - \\
\hline & $\begin{array}{l}45-54 \\
55-64 \\
65+ \\
\end{array}$ & $\begin{array}{r}2 \\
2 \\
- \\
\end{array}$ & $\begin{array}{l}9 \\
7 \\
2 \\
\end{array}$ & $\begin{array}{r}4 \\
3 \\
\end{array}$ & $\begin{array}{l}7 \\
6 \\
\end{array}$ & $\begin{array}{l}\overline{2} \\
1 \\
\end{array}$ & $\bar{z}$ & $\begin{array}{l}11 \\
22 \\
12\end{array}$ & $\begin{array}{r}80 \\
91 \\
100\end{array}$ & $\begin{array}{l}65 \\
90 \\
96\end{array}$ & $\begin{array}{l}\overline{59} \\
83\end{array}$ \\
\hline & Total 45 - & 4 & 18 & 7 & 13 & 3 & - & 45 & 91 & 88 & 51 \\
\hline & Total $15+$ & 34 & 27 & 7 & 13 & 3 & - & 84 & 60 & 57 & 27 \\
\hline
\end{tabular}


Of the 181 relatives included in the analyses (excluding the two who had no $X$ rays), two were parents, 100 were siblings, and 79 were offspring. The age distribution of relatives included in the analysis is shown in Table III. Apart from the 15- to 24-year age group, there was a fairly even distribution up to age 64 , after which the numbers tailed off in both sexes, more rapidly in the males but in accordance with general population trends.

\section{Results \\ Osteo-arthrosis in Relatives}

In Table III the percentages of joints affected by radiological osteo-arthrosis of at least the minimal grade in relatives are compared with the expected rates. Of the 84 male relatives, sixteen (19 per cent.) had osteo-arthrosis in five or more groups of joints against an expected rate of 10 per cent. Of the 97 female relatives, 27 ( 28 per cent.) had osteoarthrosis in five or more groups of joints against an expected 15 per cent. These differences are significant at the 5 per cent. level in males and at the 1 per cent. level in females. The differences did not appear till the 6th decade in males and the 5th decade in females, and they are therefore larger and more significant if only the $45+$ age groups are considered, the 1 per cent. level being reached in males and the 2 per thousand level in females. The number of relatives with no osteo-arthrosis was only slightly lower than expected, and at the level of three or more joints affected the difference is not as striking as at the level of five or more joints. It is clear that it is the multiple joint involvement which is familial and not the osteo-arthrosis as such.
Of the 24 spouses aged under 65 of the probands who were examined, three had osteo-arthrosis in five joints or more. Twenty of these spouses (13 males and 7 females) were in the 55- to 64-year age group, and all of those with osteo-arthrosis in five or more joints were in this age group. The proportion at this age was thus 15 per cent. which may be compared with 14 per cent. expected in the population sample and 38 per cent. in the relatives. It may be concluded that the familial aggregation of multiple osteo-arthritis is in all probability genetically determined.

Since the relatives aged under 45 years did not show differences from the expected rates in multiple osteo-arthrosis or any of the other characteristics analysed in Tables IV to IX, these Tables deal only with the relatives aged 45 and over. It will be seen that these Tables are not further subdivided by age groups but instead by the presence or absence of clinical Heberden's nodes and by the sex of the proband. This was done in order to investigate whether the mode of inheritance postulated by Stecher (1955) for Heberden's nodes applies also to multiple osteo-arthrosis and other characteristics. As the age distribution within the various sub-groups is relevant for the expected rates, these Tables should be read together with the appended Table A.

Multiple osteo-arthrosis of at least minimal grade did not show remarkable differences between the various sub-groups, and these findings have therefore not been tabulated here. When a higher level of severity (Grade 3-4) was chosen, relatives of both nodal and non-nodal probands showed higher than the expected rates of involvement of

III

LEAST MINIMAL GRADE IN RELATIVES, BY AGE AND SEX

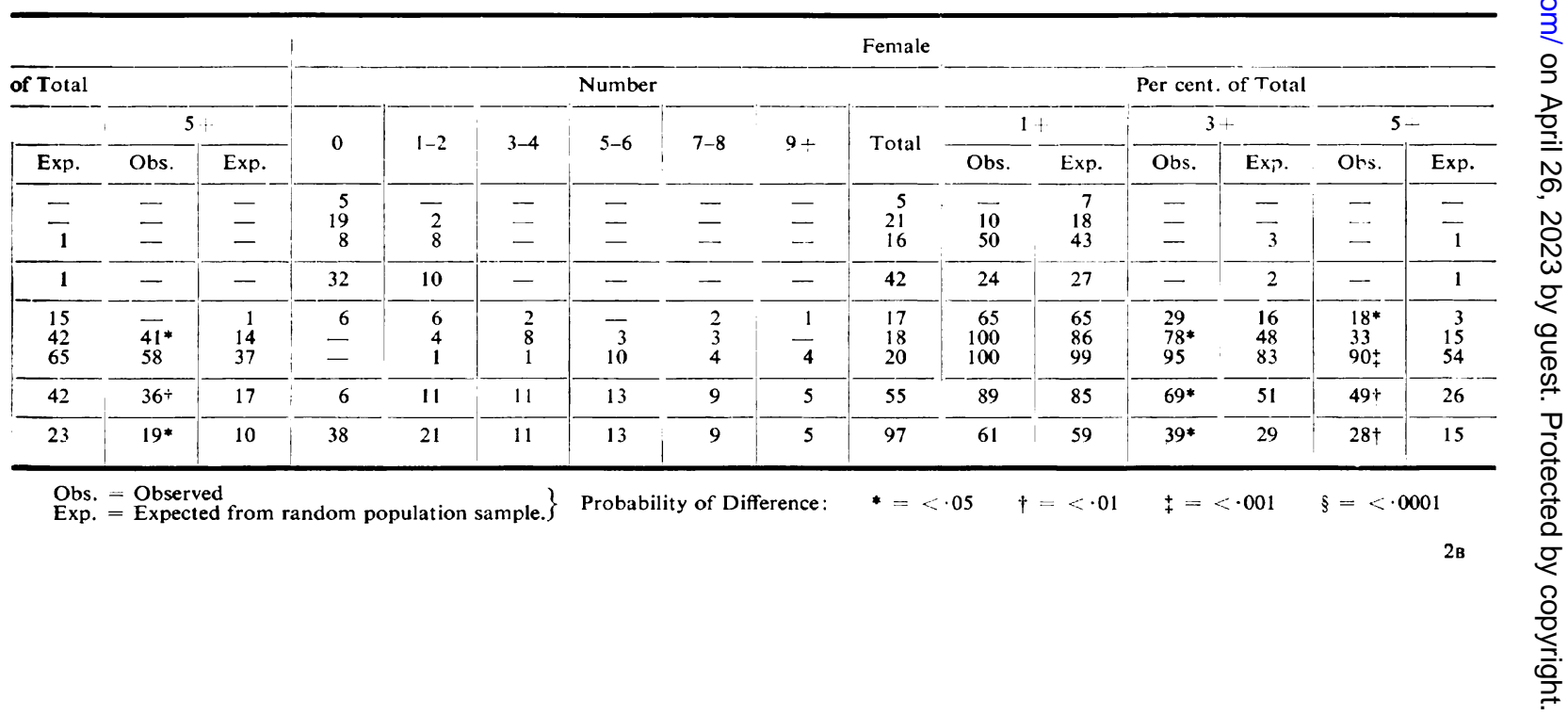


at least one group of joints, but again with little difference between the sub-groups (Table IV). More widespread involvement (more than three groups of joints) at this level of severity was still more frequent than expected in the female relatives, particularly those of the nodal probands, being significant at the 1 per thousand level. The male relatives of female probands had an excess of this degree of involvement only if the proband was nodal. The difference shown in this Table between the relatives of male and female probands within the main sub-groups are not sufficiently characteristic to be dealt with here in detail, but the reader may like to compare them with those in the following
Table V. It would appear that widespread osteoarthrosis of at least the lowest grade has a higher than expected prevalence in the relatives of both nodal and non-nodal probands, but widespread osteo-arthrosis of a higher grade of severity shows a distinct preference for the relatives of nodal probands.

\section{Clinical Heberden's Nodes}

When clinical Heberden's nodes were studied in the same way (Table V), a very distinct pattern emerged.

To minimize the influence of occupational factors in the relatives, the following comments are based

RADIOLOGICAL MULTIPLE OSTEO-ARTHROSIS OF AT LEAST MODERATE GRADE

\begin{tabular}{|c|c|c|c|c|c|c|c|c|c|c|c|}
\hline \multirow[t]{2}{*}{ Sex of Relatives .. } & \multirow[t]{2}{*}{$\cdots$} & \multirow{4}{*}{ Osteo-arthrosis } & \multicolumn{9}{|c|}{ Male } \\
\hline & & & \multicolumn{6}{|c|}{ Number } & \multicolumn{3}{|r|}{ Per cent } \\
\hline \multirow{2}{*}{\multicolumn{2}{|c|}{$\begin{array}{l}\text { Number of Joint Groups with Radiological Osteo-arthrosis } \\
\text { (Grades 3-4) in Relatives }\end{array}$}} & & \multirow{2}{*}{0} & \multirow{2}{*}{$1-2$} & \multirow{2}{*}{$3-4$} & \multirow{2}{*}{$5-6$} & \multirow{2}{*}{$7+$} & \multirow{2}{*}{ Total } & \multicolumn{2}{|c|}{$1-$} & 3 \\
\hline & & & & & & & & & Obs. & Exp. & Obs. \\
\hline \multirow{5}{*}{$\begin{array}{l}\text { Clinical } \\
\text { Heberden's Nodes } \\
\text { in } \\
\text { Probands, } \\
\text { by Sex }\end{array}$} & \multirow{2}{*}{$\begin{array}{c}\text { Non-nodal } \\
\text { (Grade 0-1) }\end{array}$} & $\begin{aligned} 11 & \text { Male } \\
5 & \text { Female }\end{aligned}$ & $\begin{array}{l}51 \\
4\end{array}$ & $\begin{array}{l}7 \\
3\end{array}$ & 1 & - & - & $\begin{array}{r}13 \\
7\end{array}$ & $\begin{array}{l}62 \\
43\end{array}$ & $\begin{array}{l}42 \\
35\end{array}$ & $\underline{8}$ \\
\hline & & 16 Male and Female & 9 & 10 & 1 & -- & - & 20 & 55 & 39 & 5 \\
\hline & \multirow{2}{*}{$\begin{array}{l}\text { Nodal } \\
\text { (Grade 2-4) }\end{array}$} & $\begin{array}{rl}6 & \mathrm{M} \\
19 & \text { Female }\end{array}$ & $\begin{array}{l}4 \\
91\end{array}$ & $\begin{array}{l}1 \\
8\end{array}$ & $-\overline{3}$ & 二 & -- & $\begin{array}{r}5 \\
21\end{array}$ & $\begin{array}{l}20 \\
57\end{array}$ & $\begin{array}{l}34 \\
37\end{array}$ & $\overline{19 *}$ \\
\hline & & 25 Male and Female & 13 & 9 & 3 & - & 1 & 26 & 50 & 37 & 15 \\
\hline & $\begin{array}{c}\text { Total } \\
\text { (Grade 0-4) }\end{array}$ & 41 Male and Female & 21 & 19 & 4 & 一 & 1 & 45 & 53 & 38 & 11 \\
\hline
\end{tabular}

1 One relative counted in two subgroups.

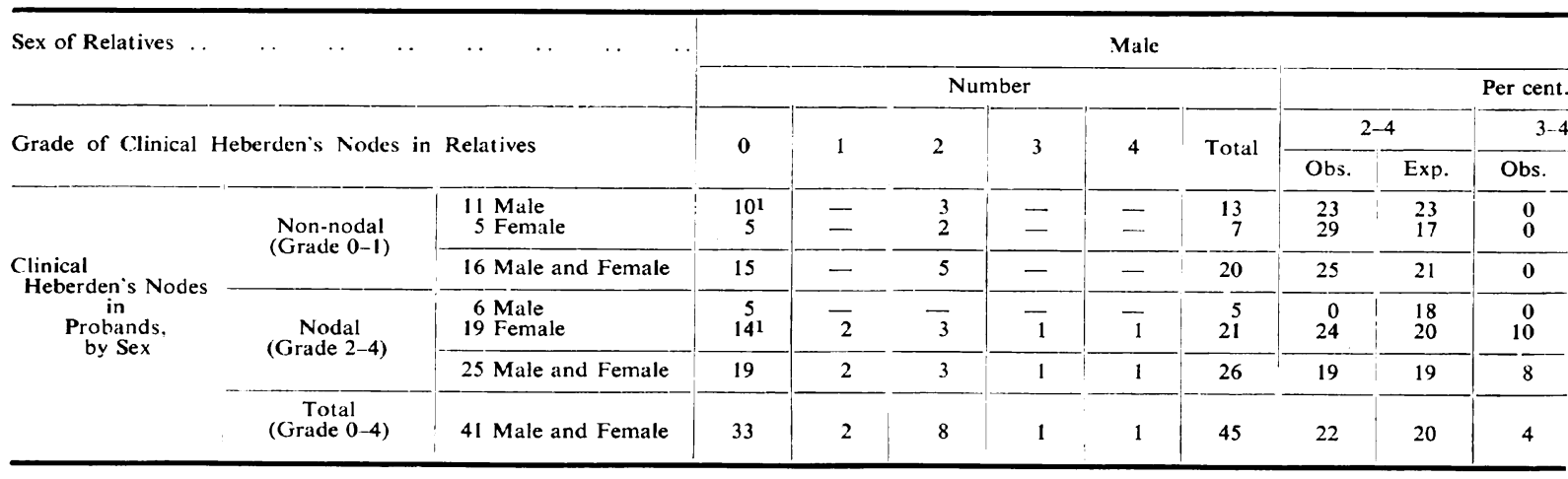


on moderate and severe (Grades 3-4) Heberden's nodes in the relatives, although the combination of minimal, moderate, and severe (Grades 2-4) Heberden's nodes is also shown in the Table. The female relatives showed a great excess over the expected rates of moderate and severe Heberden's nodes and this excess is almost limited to the relatives of nodal probands. It is particularly characteristic that the female relatives of female non-nodal probands showed no Grade 3-4 Heberden's nodes, although according to the age distribution their expected rate is the highest among the various subgroups. The female relatives of male nodal probands show a fractionally lower proportion of moderate and severe Heberden's nodes than the relatives of the female nodal probands, but this is somewhat deceptive in view of the enormous difference in age distribution: the former have eight times and the latter four times the expected rates and, although there are not more than seven female relatives aged $45+$ years of male nodal probands, the difference from the expected rate in this extremely small sub-group is significant at the 1 per cent. level. Among the male relatives, the only sub-group showing moderate and severe Heberden's nodes is that belonging to the female nodal probands, which would not entirely agree with the findings on the female side, but, as it

IV

IN RELATIVES AGED 45 + OF NODAL AND NON-NODAI. PROBANDS, BY SEX

\begin{tabular}{|c|c|c|c|c|c|c|c|c|c|c|c|c|c|c|c|}
\hline \multirow{4}{*}{$\begin{array}{l}\text { of Total } \\
\text { Exp. }\end{array}$} & \multicolumn{10}{|c|}{ Female } & \multicolumn{5}{|c|}{ Both Sexes } \\
\hline & \multicolumn{6}{|c|}{ Number } & \multicolumn{4}{|c|}{ Per cent. of Total } & \multirow{3}{*}{$\begin{array}{c}\text { Total } \\
\text { No. }\end{array}$} & \multicolumn{4}{|c|}{ Per cent. of Total } \\
\hline & \multirow{2}{*}{0} & \multirow{2}{*}{$1-2$} & \multirow{2}{*}{$3-4$} & \multirow{2}{*}{$5-6$} & \multirow{2}{*}{$7+$} & \multirow{2}{*}{ Total } & \multicolumn{2}{|c|}{$1 \div$} & \multicolumn{2}{|c|}{$3+$} & & \multicolumn{2}{|c|}{$1+$} & \multicolumn{2}{|c|}{$3+$} \\
\hline & & & & & & & Obs. & Exp. & Obs. & Exp. & & Obs. & Exp. & Obs. & Exp. \\
\hline $\begin{array}{l}8 \\
5\end{array}$ & $\begin{array}{l}5 \\
3\end{array}$ & $\begin{array}{l}6 \\
4\end{array}$ & $\begin{array}{l}2 \\
0\end{array}$ & $\begin{array}{l}1 \\
1\end{array}$ & $\overline{2}$ & $\begin{array}{l}14 \\
10\end{array}$ & $\begin{array}{l}64 \\
70\end{array}$ & $\begin{array}{l}37 \\
51\end{array}$ & $\begin{array}{l}21 \\
30\end{array}$ & $\begin{array}{l}11 \\
18\end{array}$ & $\begin{array}{l}27 \\
17\end{array}$ & $\begin{array}{l}63^{*} \\
59\end{array}$ & $\begin{array}{l}40 \\
44\end{array}$ & $\begin{array}{l}15 \\
18\end{array}$ & $\begin{array}{l}10 \\
13\end{array}$ \\
\hline 7 & 8 & 10 & 2 & 2 & 2 & 24 & $67 *$ & 43 & 25 & 14 & 44 & $61^{*}$ & 41 & 16 & 11 \\
\hline $\begin{array}{l}5 \\
6\end{array}$ & $\begin{array}{l}3 \\
6\end{array}$ & $\begin{array}{l}3 \\
5\end{array}$ & $\begin{array}{l}1 \\
8\end{array}$ & $\overline{4}$ & $\overline{1}$ & $\begin{array}{r}7 \\
24\end{array}$ & $\begin{array}{l}57 \\
75\end{array}$ & $\begin{array}{l}34 \\
48\end{array}$ & $\begin{array}{l}14 \\
54 \ddagger\end{array}$ & $\begin{array}{r}4 \\
17\end{array}$ & $\begin{array}{l}12 \\
45\end{array}$ & $\begin{array}{l}42 \\
67\end{array}$ & $\begin{array}{l}34 \\
43\end{array}$ & $\begin{array}{c}8 \\
36 \S\end{array}$ & $\begin{array}{r}5 \\
12\end{array}$ \\
\hline 6 & 9 & 8 & 9 & 4 & 1 & 31 & $71+$ & 45 & $45 \ddagger$ & 14 & 57 & $61 \dagger$ & 41 & $32 \ddagger$ & 10 \\
\hline 7 & 17 & 18 & 11 & 6 & 3 & 55 & $69 \dagger$ & 44 & $36 \ddagger$ & 14 & 100 & $62+$ & 41 & $25 \ddagger$ & 11 \\
\hline
\end{tabular}

V

OF NODAL AND NON-NODAL PROBANDS, BY SEX

\begin{tabular}{|c|c|c|c|c|c|c|c|c|c|c|c|c|c|c|c|}
\hline \multirow{4}{*}{$\begin{array}{l}\text { of Total } \\
\text { Exp. }\end{array}$} & \multicolumn{10}{|c|}{ Female } & \multicolumn{5}{|c|}{ Both Sexes } \\
\hline & \multicolumn{6}{|c|}{ Number } & \multicolumn{4}{|c|}{ Per cent. of Total } & \multirow{3}{*}{$\begin{array}{l}\text { Total } \\
\text { No. }\end{array}$} & \multicolumn{4}{|c|}{ Per cent. of Total } \\
\hline & \multirow{2}{*}{0} & \multirow{2}{*}{1} & \multirow{2}{*}{2} & \multirow{2}{*}{3} & \multirow{2}{*}{4} & \multirow{2}{*}{ Total } & \multicolumn{2}{|c|}{$2-4$} & \multicolumn{2}{|c|}{$3-4$} & & \multicolumn{2}{|c|}{$2-4$} & \multicolumn{2}{|c|}{$3-4$} \\
\hline & & & & & & & Obs. & Exp. & Obs. & Exp. & & Obs. & Exp. & Obs. & Exp. \\
\hline $\begin{array}{l}6 \\
4\end{array}$ & $\begin{array}{l}9 \\
5\end{array}$ & $\overline{1}$ & $\begin{array}{l}2 \\
4\end{array}$ & 2 & 1 & $\begin{array}{l}14 \\
10\end{array}$ & $\begin{array}{l}36 \\
40\end{array}$ & $\begin{array}{l}29 \\
38\end{array}$ & $\begin{array}{r}21 \\
0\end{array}$ & $\begin{array}{r}8 \\
12\end{array}$ & $\begin{array}{l}27 \\
17\end{array}$ & $\begin{array}{l}30 \\
35\end{array}$ & $\begin{array}{l}26 \\
29\end{array}$ & 11 & $\begin{array}{l}7 \\
9\end{array}$ \\
\hline 5 & 14 & 1 & 6 & 2 & 1 & 24 & 38 & 32 & 13 & 10 & 44 & 32 & 27 & 7 & 8 \\
\hline $\begin{array}{l}5 \\
5\end{array}$ & $\begin{array}{l}3 \\
4\end{array}$ & 1 & $\overline{8}$ & 2 & $\frac{1}{4}$ & $\begin{array}{r}7 \\
24\end{array}$ & $\begin{array}{l}43 \\
79 \S\end{array}$ & $\begin{array}{l}28 \\
36\end{array}$ & $\begin{array}{l}43 \dagger \\
46 \S\end{array}$ & $\begin{array}{r}5 \\
11\end{array}$ & $\begin{array}{l}12 \\
45\end{array}$ & $\begin{array}{l}25 \\
53 \dagger\end{array}$ & $\begin{array}{l}24 \\
28\end{array}$ & $\begin{array}{l}25 \\
29 \ddagger\end{array}$ & $\begin{array}{l}5 \\
8\end{array}$ \\
\hline 5 & 7 & 2 & 8 & 9 & 5 & 31 & $71 \S$ & 34 & $45 \S$ & 10 & 57 & $47 \dagger$ & 27 & $28 \ddagger$ & 8 \\
\hline 5 & 21 & 3 & 14 & 11 & 6 & 55 & $56 \dagger$ & 33 & $31 \ddagger$ & 10 & 100 & $41 \dagger$ & 27 & $19+$ & 8 \\
\hline
\end{tabular}


happened, two of the three male nodal probands who had female relatives with moderate and severe Heberden's nodes had no male relatives examined.

These findings were surprising since all probands in this study had radiological evidence of osteoarthrosis in the distal interphalangeal joints. This may be compared with the rate of less than 60 per cent. in the random population sample of the relevant age. In the relatives, radiological osteo-arthrosis of the distal interphalangeal joints was at about the expected level in males and significantly above the expected level in females, whether the proband's radiological affection of the distal interphalangeal joints was merely Grade 2 or Grade 3-4. However, an analysis of radiological osteo-arthrosis in the distal interphalangeal joints of the relatives according to the grouping by clinical Heberden's nodes in the proband-not tabulated here-showed a distinct preference for moderate and severe osteo-arthrosis of the distal interphalangeal joints for the female relatives of the nodal probands, those of female nodal probands showing more than twice, those of the male nodal probands more than three times the expected rates-a finding very similar to that shown for clinical Heberden's nodes; the male relatives had throughout only about the expected rates, which is also in keeping with these results. The explanation for the finding that the grouping of the probands by merely minimal and at least moderate radiological osteo-arthrosis in the distal interphalangeal joints did not show as distinct a picture as the grouping by the presence or absence of clinical Heberden's nodes appears to be as follows:
Osteo-arthrosis of the distal interphalangeal joints embraces a variety of conditions, in all of which occupation plays an important role. The Heberden's node (the bony spur on the dorsum of the finger preceded by a soft node of a few months' duration) is a feature of one type of osteo-arthrosis of the distal interphalangeal joint. Technically, it is generally easier to assess Heberden's nodes by clinical than by radiological examination, since the usual antero-posterior radiograph does not always show them clearly.

In view of the very significant association between Heberden's nodes and multiple osteo-arthrosis found in the Leigh population sample (Kellgren and Lawrence, 1958), and of the findings in this study, it seems most likely that in multiple osteo-arthrosis at least two genes are involved, one of which is associated with the occurrence of Heberden's nodes, the other(s) being independent of this feature. In an earlier study of the families of persons with rheumatoid arthritis, a slightly increased prevalence of multiple osteo-arthrosis was observed in the relatives (Lawrence and Ball, 1958). It seemed worthwhile therefore to examine the prevalence of rheumatoid arthritis in the osteoarthritic families.

\section{Rheumatoid Characteristics in Osteo-arthritic Families}

None of the characteristics belonging to the rheumatoid syndrome investigated here was found more frequently than expected in the relatives aged

INFLAMMATORY POLYARTHRITIS IN RELATIVES AGgुD

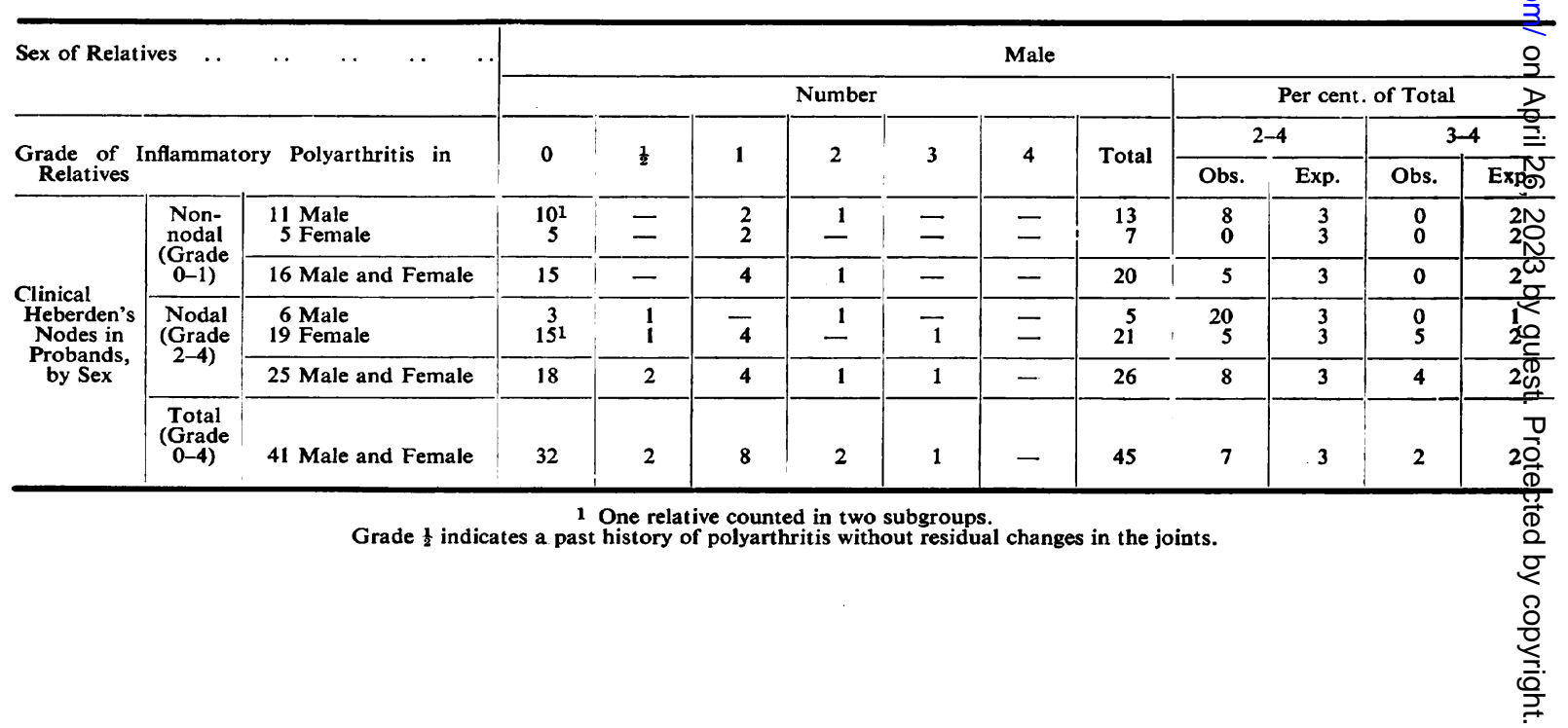


less than 45 years, ${ }^{*}$ and the Tables referring to these characteristics have therefore been limited like the two previous Tables to relatives aged over 45 years.

Clinical Inflammatory Polyarthritis (Table VI).The prevalence in all the male relatives and in the female relatives of nodal probands is much as expected, while the female relatives of non-nodal probands show roughly five times the expected rate.

Erosive Arthritis.-The findings in $x$ rays of the hands and feet (Table VII, overleaf) support those on clinical inflammatory polyarthritis. There was roughly five times the expected rate in female relatives of non-nodal probands. These results must be viewed with reservation, since the assessment of erosive arthritis in films showing widespread osteoarthrosis is most difficult. The same observer did a second reading of part of these films-not tabulated here-mixed with films which also showed widespread osteo-arthrosis, and on this occasion he gave substantially lower gradings for erosive arthritis in many instances.

Sensitized Sheep Cell Agglutination Test.-The data are slightly less complete than those on the characteristics dealt with so far, since no blood

\footnotetext{
* Inflammatory polyarthritis was found in only two females, a past history of polyarthritis without residual changes in two males and two females, erosive arthritis in only one male, and a positive sheep cell agglutination test in only two females; one male and one female had morning stiffness of more than 15 minutes' duration.
}

sample could be obtained or the test failed in six instances. We have to mention especially that no sheep cell agglutination test was done on a female relative suffering from severe inflammatory and erosive arthritis who belonged to a female nonnodal proband. We do not think, however, that the few omissions have substantially altered the picture, which shows practically no difference from the expected rates throughout the sample, 9 per cent. positive tests observed as against 8 per cent. expected (Table VIII, overleaf).

Morning Stiffness (Table IX, overleaf).-The prevalence was slightly but not significantly higher than expected only among the female relatives of nonnodal probands.

Genetic Tables.-Rheumatoid characteristics among relatives were largely encountered in six families, in two of which the proband had S.C.A.T. positive rheumatoid arthritis and in one of which the proband had S.C.A.T. negative psoriatic arthritis. In one of the other three families the proband showed osteo-arthrosis which was thought to be secondary to rheumatoid arthritis. In the remaining two the proband had a doubtful result with the S.C.A.T. (titre 1/16).

Two of the above-mentioned arthritic probands were non-nodal males, one S.C.A.T. positive, one negative.

The S.C.A.T. positive non-nodal male proband had one brother and four sisters aged over 45 years examined. Two of the sisters had severe clinical and radiological rheuma-

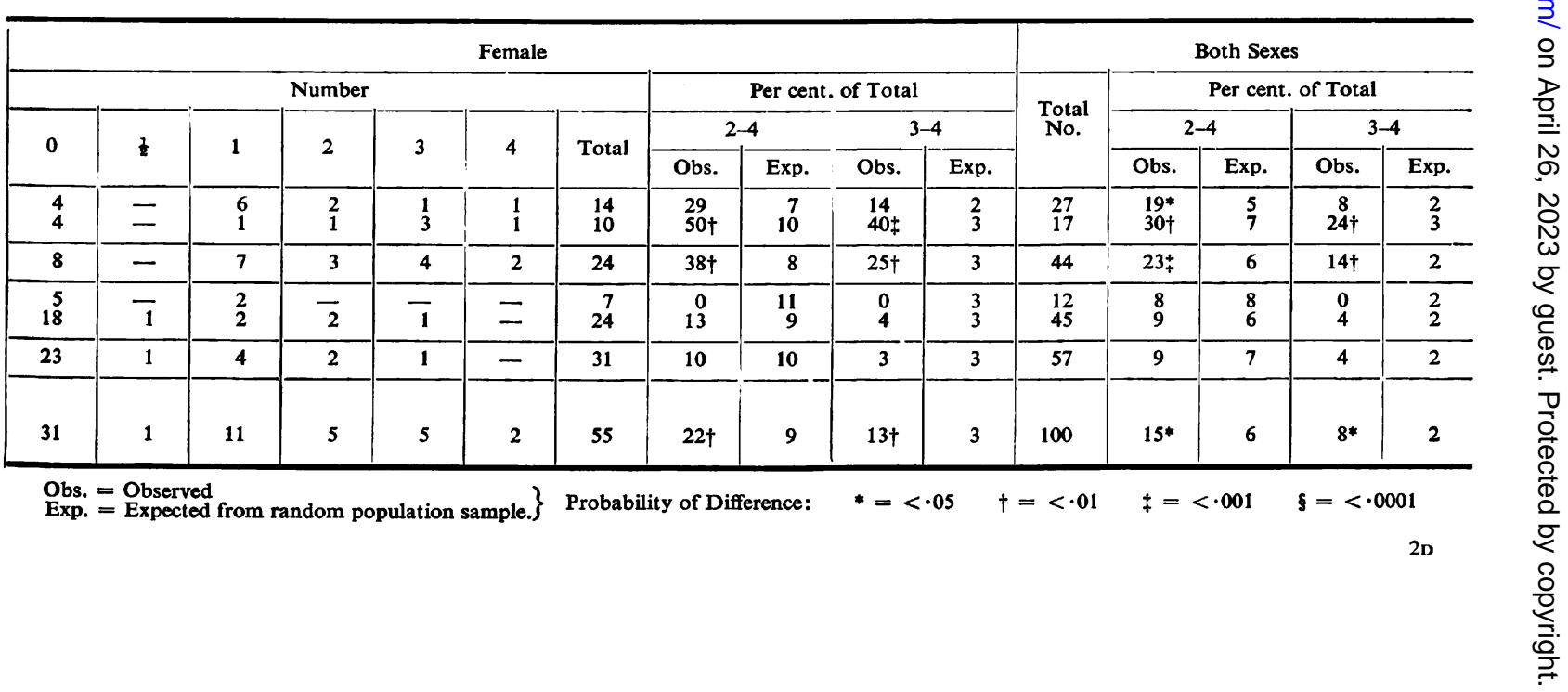


EROSIVE ARTHRITIS IN HANDS AND FEET IN RELATIVE⿻̧̣?

\begin{tabular}{|c|c|c|c|c|c|c|c|c|c|c|c|}
\hline \multirow[t]{2}{*}{ Sex of Relatives .. } & \multirow[t]{2}{*}{$\cdots$} & \multirow[t]{4}{*}{.. } & \multicolumn{9}{|c|}{ Male } \\
\hline & & & \multicolumn{6}{|c|}{ Number } & \multicolumn{3}{|c|}{ Per cent. of } \\
\hline \multirow{2}{*}{\multicolumn{2}{|c|}{ Grade of Erosive Arthritis in Relatives }} & & \multirow{2}{*}{0} & \multirow{2}{*}{1} & \multirow{2}{*}{2} & \multirow{2}{*}{3} & \multirow{2}{*}{4} & \multirow{2}{*}{ Total } & \multicolumn{2}{|c|}{$2-4$} & $3-4$ \\
\hline & & & & & & & & & Obs. & Exp. & Obs. \\
\hline \multirow{5}{*}{$\begin{array}{c}\text { Clinical } \\
\text { Heberden's } \\
\text { Nodes } \\
\text { in } \\
\text { Probands, } \\
\text { by Sex }\end{array}$} & \multirow{2}{*}{$\begin{array}{c}\text { Non-nodal } \\
\text { (Grade 0-1) }\end{array}$} & $\begin{array}{l}11 \text { Male } \\
5 \text { Female }\end{array}$ & $\begin{array}{l}51 \\
7\end{array}$ & $\underline{8}$ & - & - & - & $\begin{array}{r}13 \\
7\end{array}$ & $\begin{array}{l}0 \\
0\end{array}$ & $\begin{array}{l}8 \\
7\end{array}$ & $\begin{array}{l}0 \\
0\end{array}$ \\
\hline & & 16 Male and Female & 12 & 8 & - & 一 & - & 20 & $\mathbf{0}$ & 8 & 0 \\
\hline & \multirow{2}{*}{$\begin{array}{c}\text { Nodal } \\
\text { (Grade 2-4) }\end{array}$} & $\begin{array}{l}6 \text { Male } \\
19 \text { Female }\end{array}$ & $\stackrel{3}{10^{1}}$ & 2 & $\overline{2}$ & $\overline{1}$ & -1 & $\begin{array}{r}5 \\
21\end{array}$ & $\begin{array}{r}0 \\
19\end{array}$ & $\begin{array}{l}6 \\
7\end{array}$ & $\begin{array}{r}0 \\
10\end{array}$ \\
\hline & & 25 Male and Female & 13 & 9 & 2 & 1 & 1 & 26 & 15 & 7 & 8 \\
\hline & $\begin{array}{c}\text { Total } \\
\text { (Grade 0-4) }\end{array}$ & 41 Male and Female & 24 & 17 & & 1 & 1 & 45 & 9 & 7 & 4 \\
\hline
\end{tabular}

I One relative counted in two subgroups.

SHEEP CELL AGGLUTINATION TEST RESULTS IN RELATIVE

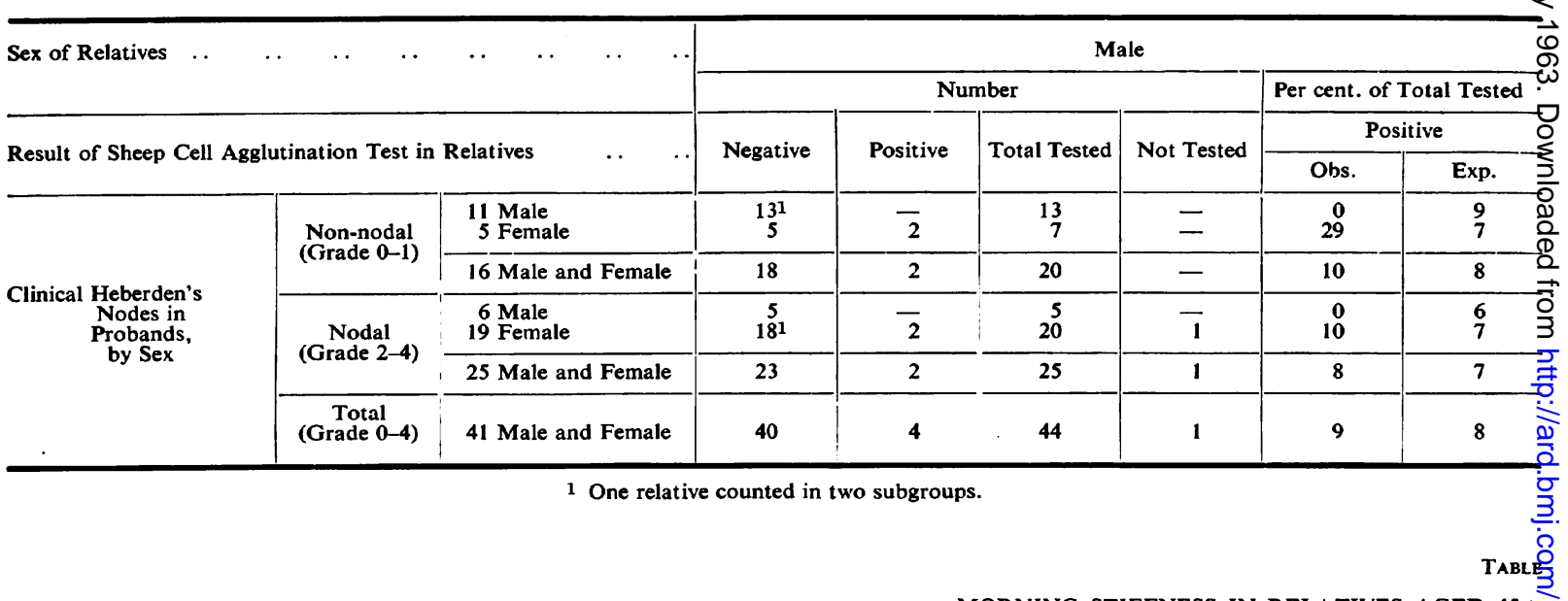

MORNING STIFFNESS IN RELATIVES AGED 45:

\begin{tabular}{|c|c|c|c|c|c|c|c|c|c|c|}
\hline \multirow[t]{2}{*}{ Sex of Relatives } & \multirow[t]{2}{*}{. } & \multirow{2}{*}{$\cdots$} & \multirow[t]{2}{*}{.. } & \multirow{2}{*}{. } & \multicolumn{6}{|c|}{ Male } \\
\hline & & & & & \multicolumn{4}{|c|}{ Number } & \multirow{2}{*}{\multicolumn{2}{|c|}{$\begin{array}{l}\text { Per cent. of Total } \\
\text { Over } \$ \text { hr }\end{array}$}} \\
\hline \multirow{2}{*}{\multicolumn{2}{|c|}{ Duration of Morning Stiffness in Relatives }} & & & & & & & & & \\
\hline & & $\cdots$ & $\cdots$ & $\cdots$ & PVouc & opto & ovet $1 \mathrm{ir}$ & Tota! & Obs. & Exp. \\
\hline \multirow{5}{*}{$\begin{array}{c}\text { Clinical Heberden's } \\
\text { Nodes in } \\
\text { Probands, } \\
\text { by Sex }\end{array}$} & \multirow{2}{*}{$\begin{array}{l}\text { Non-nodal } \\
\text { (Grade 0-1) }\end{array}$} & 11 & $\begin{array}{l}\text { ale } \\
\text { male }\end{array}$ & & $\begin{array}{l}9 \\
6\end{array}$ & $\underline{31}$ & $\begin{array}{l}1 \\
1\end{array}$ & $\begin{array}{r}13 \\
7\end{array}$ & $\begin{array}{r}8 \\
14\end{array}$ & $\begin{array}{l}13 \\
14\end{array}$ \\
\hline & & 16 & ale an & Female & 15 & 3 & 2 & 20 & 10 & 14 \\
\hline & \multirow{2}{*}{$\underset{\text { (Grade 2-4) }}{\text { Nodal }}$} & $\begin{array}{r}6 \\
19\end{array}$ & $\begin{array}{l}\text { ale } \\
\text { male }\end{array}$ & & $\begin{array}{r}4 \\
14\end{array}$ & $\overline{51}$ & $\begin{array}{l}1 \\
2\end{array}$ & 21 & $\begin{array}{l}20 \\
10\end{array}$ & $\begin{array}{l}14 \\
14\end{array}$ \\
\hline & & 25 & ale an & Female & 18 & 5 & 3 & 26 & 12 & 14 \\
\hline & $\begin{array}{c}\text { Total } \\
\text { (Grade 0-4) }\end{array}$ & \multicolumn{3}{|c|}{41 Male and Female } & 33 & 7 & 5 & 45 & 11 & 14 \\
\hline
\end{tabular}


VII

AGED 45 OF NODAL AND NON-NODAL PROBANDS, BY SEX

\begin{tabular}{|c|c|c|c|c|c|c|c|c|c|c|c|c|c|c|c|}
\hline \multirow{4}{*}{$\begin{array}{l}\text { Total } \\
\text { Exp. }\end{array}$} & \multicolumn{10}{|c|}{ Female } & \multicolumn{5}{|c|}{ Both Sexes } \\
\hline & \multicolumn{6}{|c|}{ Number } & \multicolumn{4}{|c|}{ Per cent. of Total } & \multicolumn{5}{|c|}{ Per cent. of Total } \\
\hline & \multirow{2}{*}{0} & \multirow{2}{*}{1} & \multirow{2}{*}{2} & \multirow{2}{*}{3} & \multirow{2}{*}{4} & \multirow{2}{*}{ Total } & \multicolumn{2}{|c|}{$2-4$} & \multicolumn{2}{|c|}{$3-4$} & \multirow[t]{2}{*}{ No. } & \multicolumn{2}{|c|}{$2-4$} & \multicolumn{2}{|c|}{$3-4$} \\
\hline & & & & & & & Obs. & Exp. & Obs. & Exp. & & Obs. & Exp. & Obs. & Exp. \\
\hline $\begin{array}{l}2 \\
1 \\
\end{array}$ & $\begin{array}{l}6 \\
3\end{array}$ & $\begin{array}{l}3 \\
5\end{array}$ & $\frac{3}{-}$ & $\overline{1}$ & $\begin{array}{l}2 \\
1\end{array}$ & $\begin{array}{l}14 \\
10\end{array}$ & $\begin{array}{l}36_{+}^{+} \\
20^{+}\end{array}$ & $\begin{array}{l}5 \\
9\end{array}$ & $\begin{array}{l}14 \\
20 \\
\end{array}$ & $\begin{array}{l}1 \\
2\end{array}$ & $\begin{array}{l}27 \\
17\end{array}$ & $\begin{array}{l}19 \\
12\end{array}$ & $\begin{array}{l}7 \\
8\end{array}$ & $\begin{array}{r}8 \\
12\end{array}$ & $\begin{array}{l}2 \\
2\end{array}$ \\
\hline 2 & 9 & 8 & 3 & 1 & 3 & 24 & $29+$ & 7 & $17 \dagger$ & 2 & 44 & 16 & 7 & $9^{*}$ & 2 \\
\hline $\begin{array}{l}1 \\
1 \\
\end{array}$ & $\begin{array}{r}5 \\
11\end{array}$ & $\begin{array}{l}2 \\
8\end{array}$ & $-\overline{2}$ & 1 & $\overline{2}$ & $\begin{array}{r}7 \\
24\end{array}$ & $\begin{array}{r}0 \\
21\end{array}$ & $\begin{array}{l}6 \\
8\end{array}$ & $\begin{array}{r}0 \\
13\end{array}$ & $\begin{array}{l}1 \\
2\end{array}$ & $\begin{array}{l}12 \\
45 \\
\end{array}$ & $\begin{array}{c}0 \\
20^{*}\end{array}$ & $\begin{array}{l}6 \\
8\end{array}$ & $11 \div$ & $\begin{array}{l}1 \\
2\end{array}$ \\
\hline 7 & 16 & 10 & 2 & 1 & 2 & 31 & 16 & 8 & 10 & 2 & 57 & 16 & 7 & $9 \div$ & $-\overline{2}$ \\
\hline 1 & 25 & 18 & 5 & 2 & 5 & 55 & $22 \dagger$ & 7 & $13 \dagger$ & 2 & 100 & $16^{*}$ & 7 & $9 \%$ & 2 \\
\hline
\end{tabular}

Obs. $=$ Observed
Exp. $=$ Expected from random population sample. $\}$ Pro

Probability of Difference:

$*-=0.05$

VIII

AGED $45+$ OF NODAL AND NON-NODAL PROBANDS, BY SEX

\begin{tabular}{|c|c|c|c|c|c|c|c|c|}
\hline \multicolumn{6}{|c|}{ Female } & \multicolumn{3}{|c|}{ Both Sexes } \\
\hline \multicolumn{3}{|c|}{ Number } & & \multirow{2}{*}{\multicolumn{2}{|c|}{$\frac{\text { Per cent. of Total Tested }}{\text { Positive }}$}} & \multirow{3}{*}{$\begin{array}{l}\text { Totial } \\
\text { No. } \\
\text { Tested }\end{array}$} & Per cen & Tested \\
\hline \multirow{2}{*}{ Negative } & \multirow{2}{*}{ Positive } & \multirow{2}{*}{ Total Tested } & \multirow{2}{*}{ Not Tested } & & & & \multicolumn{2}{|c|}{ Positive } \\
\hline & & & & Obs. & Exp. & & Obs. & Exp. \\
\hline $\begin{array}{r}11 \\
9\end{array}$ & 2 & $\begin{array}{r}13 \\
9\end{array}$ & 1 & $\begin{array}{r}15 \\
0\end{array}$ & $\begin{array}{l}8 \\
8\end{array}$ & $\begin{array}{l}26 \\
16\end{array}$ & $\begin{array}{r}8 \\
13\end{array}$ & $\begin{array}{l}8 \\
7\end{array}$ \\
\hline 20 & 2 & 22 & 2 & 9 & 8 & 42 & 10 & 8 \\
\hline $\begin{array}{r}7 \\
19\end{array}$ & $\overline{2}$ & $\begin{array}{r}7 \\
21\end{array}$ & 3 & $\begin{array}{r}0 \\
10 \\
\end{array}$ & $\begin{array}{l}6 \\
8\end{array}$ & $\begin{array}{l}12 \\
41\end{array}$ & $\begin{array}{r}0 \\
10\end{array}$ & $\begin{array}{l}6 \\
8\end{array}$ \\
\hline 26 & 2 & 28 & 3 & 7 & 8 & 53 & 8 & 7 \\
\hline 46 & 4 & 50 & 5 & 8 & 8 & 94 & 9 & 8 \\
\hline
\end{tabular}

IX

OF NODAL AND NON-NODAL PROBANDS, BY SEX

\begin{tabular}{|c|c|c|c|c|c|c|c|c|}
\hline \multicolumn{6}{|c|}{ Female } & \multicolumn{3}{|c|}{ Both Sexes } \\
\hline \multicolumn{3}{|c|}{ Number } & \multirow{3}{*}{ Total } & \multirow{2}{*}{\multicolumn{2}{|c|}{$\begin{array}{l}\text { Per cent. of Total } \\
\text { Over } 4 \mathrm{hr}\end{array}$}} & \multirow{3}{*}{$\begin{array}{l}\text { Total } \\
\text { No. }\end{array}$} & \multirow{2}{*}{\multicolumn{2}{|c|}{$\begin{array}{l}\text { Per cent. of Total } \\
\text { Over } \$ \mathrm{hr}\end{array}$}} \\
\hline \multirow{2}{*}{ None } & \multirow{2}{*}{ Un to $1 \mathrm{hr}$} & \multirow{2}{*}{ Over $\frac{1}{4}$ hr } & & & & & & \\
\hline & & & & Obs. & Exp. & & Obs. & Exp. \\
\hline $\begin{array}{l}8 \\
5 \\
\end{array}$ & $\begin{array}{l}1 \\
2\end{array}$ & 5 & $\begin{array}{l}14 \\
10\end{array}$ & $\begin{array}{l}36 \\
30\end{array}$ & $\begin{array}{l}16 \\
17\end{array}$ & $\begin{array}{l}27 \\
17\end{array}$ & 22 & $\begin{array}{l}15 \\
16 \\
\end{array}$ \\
\hline 13 & 3 & 8 & 24 & 33 & 17 & 44 & 23 & 15 \\
\hline $\begin{array}{r}6 \\
15\end{array}$ & $\begin{array}{l}1 \\
5\end{array}$ & 4 & $\begin{array}{r}7 \\
24\end{array}$ & $\begin{array}{r}0 \\
17\end{array}$ & $\begin{array}{l}20 \\
17\end{array}$ & $\begin{array}{l}12 \\
45\end{array}$ & $\begin{array}{r}8 \\
13\end{array}$ & $\begin{array}{l}18 \\
16 \\
\end{array}$ \\
\hline 21 & 6 & 4 & 31 & 13 & 18 & 57 & 12 & 16 \\
\hline 34 & 9 & 12 & 55 & 22 & 17 & 100 & 17 & 16 \\
\hline
\end{tabular}


toid arthritis with positive S.C.A.T. Another sister was affected only clinically and the fourth only radiologically (the films of the latter were on the second reading not classed as rheumatoid). The brother over 45 years and three younger relatives showed no rheumatoid characteristics. None of the relatives had Heberden's nodes, but the severe rheumatoid arthritics also had widespread multiple osteo-arthrosis.

The S.C.A.T. negative non-nodal male proband with psoriatic arthritis had one brother and three sisters aged over 45 years examined. In this family radiological rheumatoid characteristics affected only two of the sisters, who both had also widespread multiple osteo-arthrosis and Heberden's nodes (on the second reading their films were not regarded as definitely rheumatoid).

These two families explain the concentration of rheumatoid characteristics in the female relatives of the male non-nodal probands.

It should be mentioned that there were two further S.C.A.T. positive rheumatoid arthritics among the male non-nodal probands, but one of them had only two young daughters, and the other had two siblings over 45 years and two young offspring included in the study none of whom showed rheumatoid characteristics. The fact that amongst the thirteen male non-nodal probands with more than six joints affected by osteo-arthrosis there were three S.C.A.T. positive and one S.C.A.T. negative arthritics must, however, be taken into account in considering the origin of multiple osteo-arthrosis, particularly in non-nodal males.

The remaining S.C.A.T. positive rheumatoid arthritic proband was a nodal female and is of particular interest. She had a serum cholesterol of $360 \mathrm{mg} . / 100 \mathrm{ml}$.

Her mother, aged 91 years and bedridden, had osteoarthrosis with Heberden's nodes, gross porosis in all bones $x$-rayed, and rheumatoid arthritis. Her S.C.A.T. titre was 1 in 8 and the test was therefore negative.

One brother had a positive S.C.A.T. (titre 1 in 128) and had been unable to work for 3 years because of pneumoconiosis. He had no rheumatic symptoms and only doubtful erosive changes in the head of one 5th metatarsal bone.

Another brother had osteo-arthrosis in four groups of joints and hypercholesterolaemia $(401 \mathrm{mg} . / 100 \mathrm{ml}$.), but he had a negative S.C.A.T. and no evidence of rheumatoid arthritis.

A third brother had asymptomatic subluxation of the lateral metatarsophalangeal joints but was otherwise normal.

The only sister examined had generalized osteoarthrosis with Heberden's nodes and her serum cholestero lwas $366 \mathrm{mg} . / 100 \mathrm{ml}$. She also had erosions in the metacarpophalangeal and carpometacarpal joints, which were regarded as rheumatoid on the second reading.

One young offspring was examined but was apparently normal.

The proband originally recorded as having osteoarthrosis secondary to rheumatoid arthritis was a nonnodal female who had one male and six female relatives aged over 45 years examined; two of the latter had rheumatoid arthritis, and one of these also had multiple osteo-arthrosis.

Finally, the two probands with doubtful S.C.A.T.s were both females, one nodal, the other non-nodal.

The latter (non-nodal) female had three brothers and one sister aged over 45 years examined; two of the brothers were S.C.A.T. positive but had no definite evidence of arthritis, the sister showed clinical rheumatoid arthritis, and all three had multiple osteo-arthrosis.

The former (nodal) female had one brother and three sisters aged over 45 years examined; one of the sisters had minimal radiological arthritis and another had clinical rheumatoid arthritis with multiple osteo-arthrosis.

For completeness it is mentioned that the female nodal probands also included one S.C.A.T. positive nonrheumatoid, who had only one relative over 45 years examined (who showed no abnormalities) and one young daughter (whose only abnormality was that she was S.C.A.T. positive).

Altogether there were nine male and nineteen female relatives over 45 years with rheumatoid characteristics. Three males and ten females belonged to the six families just described, so that familial aggregation has been traced in about half of the subjects in question. The remaining relatives with rheumatoid characteristics occurred in families with only one to three relatives over 45 years examined, in which the proband did not obviously show such characteristics.

It would thus appear that, at least in the families of individuals with multiple osteo-arthrosis, rheumatoid characteristics have a definite familial aggregation, though clinical, radiological, and serological changes may be scattered in kind and degree among the affected members.

Four of the 52 probands had sero-positive rheumatoid arthritis and one had sero-negative psoriatic arthritis, and four of these five were males and had no clinical Heberden's nodes. As it happened, they had mainly female relatives 
examined and this largely explains why in this study rheumatoid characteristics in the non-nodal families show such a distinct preference for females. If the probands were added to the relatives this sex difference would be greatly diminished, but the difference between nodal and non-nodal families would stand and clinical Heberden's nodes would still appear to be useful in distinguishing between primary and secondary osteo-arthrosis.

\section{Pattern of Joints Affected by Osteo-arthrosis}

All joints except the hips were more frequently affected by osteo-arthrosis than expected in the relatives, but the differences were most marked in the case of the upper limb joints and neck, less so in the lumbar spine, and least in the weight-bearing joints.

Between the relatives of nodal and non-nodal probands there was little difference in the males, but in the females both the distal and proximal interphalangeal joints of the fingers were more severely affected in those belonging to nodal probands. The "non-nodal" females on the other hand showed more osteo-arthrosis in the metacarpophalangeal joints and in the wrists. The general trend is thus for the "nodal" females to reflect in their joints the pattern of involvement described by Kellgren and Moore (1952) in primary generalized osteo-arthrosis, and for the "non-nodal" females to reveal a pattern consistent with osteo-arthrosis secondary to inflammatory polyarthritis.

Most of the nine female relatives of the non-nodal probands suffering from inflammatory polyarthritis also had widespread osteo-arthrosis.

Of the five whose proband was a female, two gave a long history of rheumatoid arthritis and appeared to have developed osteo-arthrosis in the rheumatoid joints, most of the joints of the hands and feet being affected; in one of them no evidence of erosive arthritis was found in the films of the hands and feet and she had a negative S.C.A.T.; the other had severe erosive arthritis but no blood sample was available for testing. In two others, both of whom had a negative S.C.A.T., the rheumatoid arthritis was of more recent onset and could have supervened on the widespread osteo-arthrosis, which however, showed involvement of some joints in females rarely affected by nodal osteo-arthrosis, especially the metacarpophalangeals and wrist joints. In the fifth there was no osteo-arthrosis. The distribution of osteo-arthrosis in all the female non-nodal probands was, as in the affected relatives, atypical for nodal osteo-arthrosis; two of these probands, though not suffering from rheumatoid arthritis, were mentioned in the above description of the aggregation of rheumatoid characteristics in a few families. Of the four female relatives with clinical rheumatoid arthritis who belonged to male non-nodal probands, all had some osteo-arthrosis, but in only two was it widespread. Here again the unusual involvement of the wrists and metacarpophalangeal joints was found. Three of these relations belonged to the same proband with severe rheumatoid arthritis.

The male relatives do not seem to follow the pattern of joint involvement observed in the female relatives. This may be partly because the male relatives are younger, particularly in the "nodal" families, but it seems likely that some other factor plays a part in the males. Gout is known to predispose to osteo-arthrosis and is found chiefly in males. It was possible to test the serum uric acid in only fifty relatives of all age groups and both sexes and in only 34 probands in this survey. There was a shift towards higher uric acid levels in the male relatives of both nodal and non-nodal probands, which corresponds to a similar shift in the male probands. The difference from the expected values is not easy to assess because two different methods were used in the determination of serum uric acid; full details are not given here, but we think that this difference closely approached the 5 per cent. level of significance. No such shift was encountered in the female probands and relatives, who showed the same distribution of uric acid levels as the random sample. More information on this point will be available when the relationship between serum uric acid and osteo-arthrosis in the random samples of the population has been studied.

Superimposed occupational patterns of joint involvement may also play a relatively more important role in males. Nearly 70 per cent. of the male relatives aged 45 years and over were miners, workers in other heavy industries, outdoor workers, or general labourers (compared with 60 per cent. in the population sample), and these are known to be prone to osteo-arthrosis in various joints. In both sexes osteo-arthrosis of the weight-bearing joints is undoubtedly determined to some extent by body habitus and this may explain why these joints do not reflect hereditary influences so closely.

\section{X-Ray Appearances in Nodal and Non-nodal Multiple Osteo-arthrosis}

The $x$-ray appearances in the nodal and nonnodal types of multiple osteo-arthrosis are illustrated 


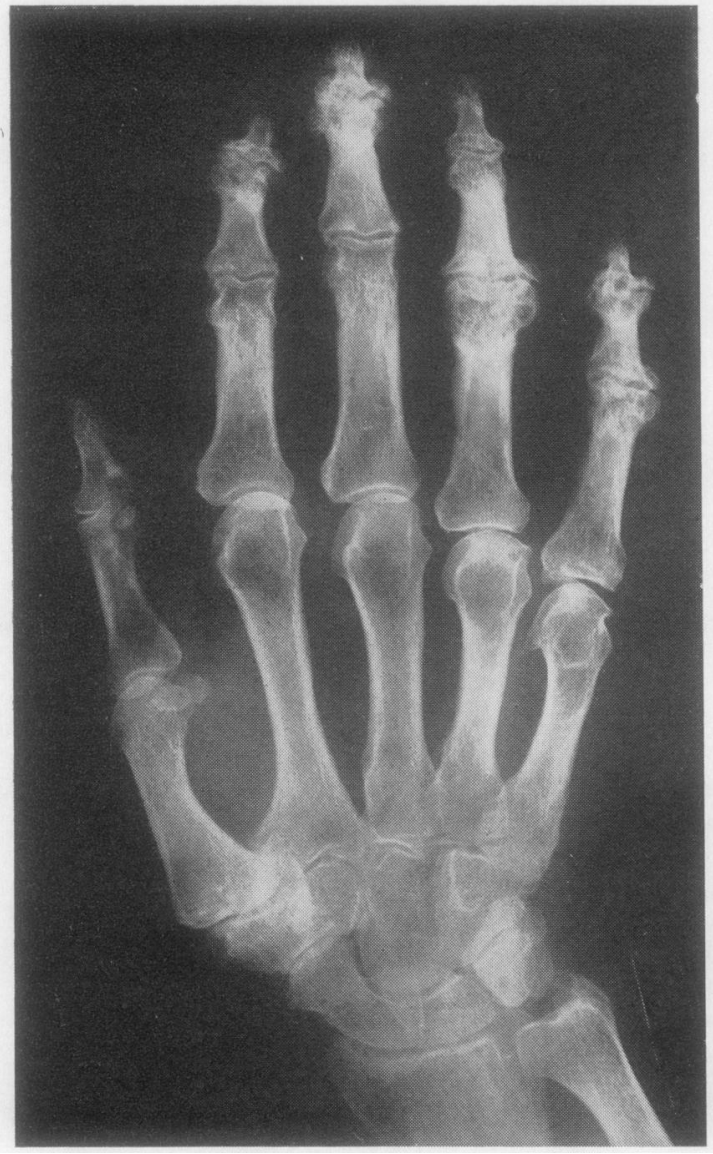

Fig. 1.-Nodal type of generalized osteo-arthrosis.

in Figs 1 and 2. In the nodal type the distal and proximal interphalangeal and first carpometacarpal joints are mainly affected, and in the non-nodal type the metacarpophalangeal joints. Erosions are seldom seen except in the presence of frank rheumatoid arthritis (Fig. 3, opposite), but the nodal type may simulate hook erosions and so result in an erroneous diagnosis of osteo-arthrosis secondary to rheumatoid arthritis. Bone cysts are present in both types of osteo-arthrosis.

\section{Serum Cholesterol Levels}

The serum cholesterol levels in our sample were studied from various aspects. These data are somewhat less complete than those on the S.C.A.T. since sufficient serum was not available for all tests in all instances.
This applies also to the probands. As far as can be judged, however, the findings in the probands were similar to those in the relatives of the appropriate age groups. The available data were expressed in mg./ $100 \mathrm{ml}$. above and below the appropriate age and sex mean in the population sample (London, Muirden, and Hewitt, 1963) and then formed into five groups, average values to comprise deviations of up to $\pm 20 \mathrm{mg}$./100 ml., moderate deviations \pm 21 to $60 \mathrm{mg}$. $/ 100 \mathrm{ml}$., and strong deviations \pm 61 and more $\mathrm{mg} . / 100 \mathrm{ml}$. from the appropriate mean.

The main results of an analysis of the findings in the relatives by the presence and absence of Heberden's nodes in the probands are shown in Table X (overleaf) for both broad age groups, under and over 45 years. It will be seen that, in the $45+$ age group, the total proportion of at least moderately raised serum cholesterol levels agrees in males and females closely with the expected values. The male relatives showed more than twice as many as expected with at least moderately raised serum

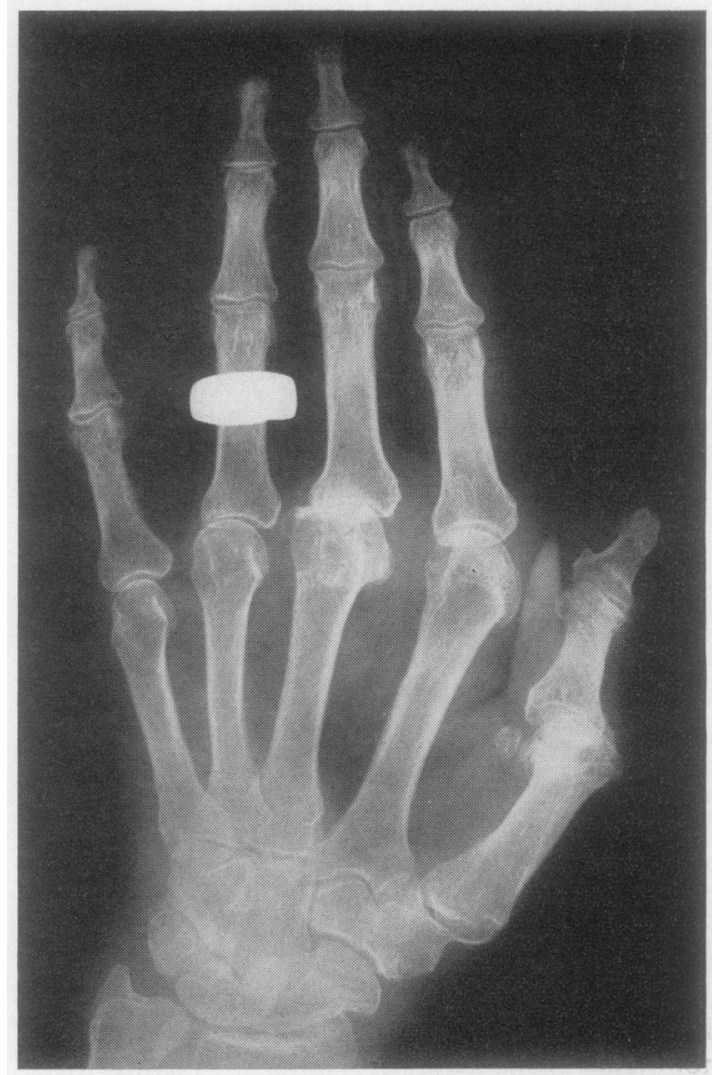

Fig. 2.-Non-nodal type of generalized osteo-arthrosis. 


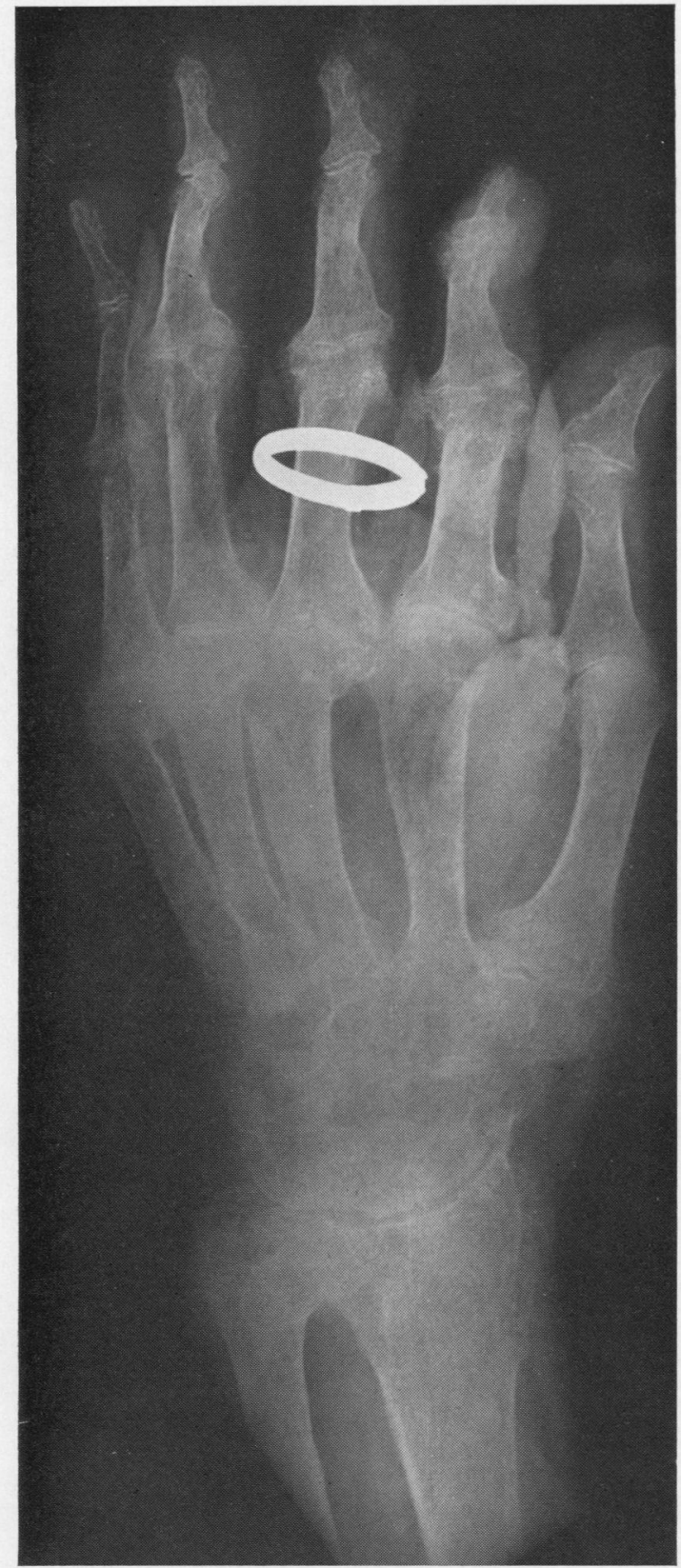

Fig. 3.-Non-nodal type of generalized osteo-arthrosis following frank rheumatoid arthritis.

cholesterol in the 15- to 44-year age group; this is statistically significant at the 1 per cent. level. On the other hand, a comparison with the Registrar-General's data for the South-East Lancashire conurbation showed no undue depletion in the ranks of the male relatives in the higher age groups. The occupational distribution offers no obvious explanation. Curiously, the male relatives of the non-nodal showed even higher values than those of the nodal probands in both age groups, which also amounts to statistical significance at the 1 per cent. level; however, the four sons, all with at least moderately raised serum cholesterol, of a male non-nodal proband weigh somewhat heavily in this small sample.

A similar analysis of serum cholesterol levels by the presence and absence of Heberden's nodes in the relatives themselves, aged $45+$ years, showed no significant difference, but the findings in the females from age 55 onwards suggested higher cholesterol levels in those with nodes, while the males again showed the opposite trend.

These data have been given in the hope that they may be of interest in connexion with further studies, but the groups are small and-in view of the many factors known to influence the serum cholesterol level-it would be unwise to draw any conclusions at this stage.

\section{Discussion}

It seems clear from this survey that genetic factors in generalized osteo-arthrosis are very complex and depend on a number of inherited characteristics. It is difficult to draw conclusions from the male part of the sample of relatives because of the lower prevalence in males of some of the factors investigated, because of the lower ages of the males in this sample which correspond to general population trends, and because occupation has a stronger influence here. It has, however, been demonstrated that the findings in the males of the sample support in many respects the findings in the females. Generalized osteo-arthrosis in females would appear to depend on two main factors:

(1) An inherited trait associated with Heberden's nodes, which gives rise to the primary osteo-arthrosis described by Kellgren and Moore;

(2) An inherited type of multiple osteoarthrosis with a pattern of joint involvement which differs from that found in the primary form and which is sometimes associated with inflammatory polyarthritis, which is predominantly S.C.A.T. negative.

Examples of this type of affection appeared among the male non-nodal probands, while the few female non-nodal probands concerned did not themselves suffer from inflammatory polyarthritis, but some of them belonged to families in which characteristics belonging to the rheumatoid syndrome were aggregated. It would seem that persons inheriting 
SERUM CHOLESTEROL IN RELATIVES OF NOW ALAL

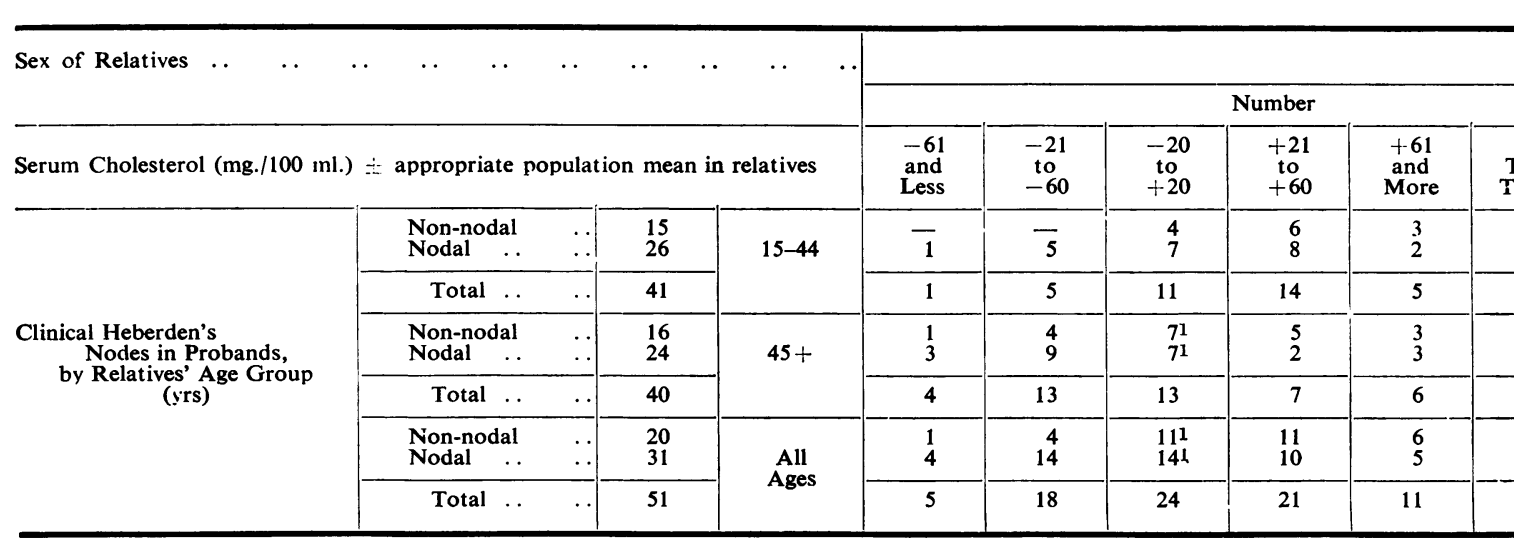

1 One relative counted in two subgroups.

this trend may develop either a frank polyarthritis or a multiple osteo-arthrosis, or a combination of these, the second being possibly a sequel of a mild unrecognized inflammatory polyarthritis.

Inheritance in the first type may be expected to be identical with that for Heberden's nodes. If Heberden's nodes are inherited as a single autosomal gene dominant in females and recessive in males, as Stecher (1955) suggests, it should in general occur only in males who are homozygous for the nodal allele and be absent only in females who lack the nodal allele. The frequency of Heberden's nodes in our random population sample is consistent with such a hypothesis. In favour of this also is the fact that, in female relatives aged $45+$ of nodal probands in this survey, Heberden's nodes Grade 3-4 were found eight times more often than expected when the proband was a male but only four times more often than expected when the proband was a female. It is still further confirmed by the complete absence of Heberden's nodes Grades 3-4 in the male and female relatives of non-nodal female probands. If the nodes were recessive in males, it would mean that males homozygous for the nodal allele would be capable of developing nodes. Heterozygous males would only develop nodes in exceptionally favourable environmental conditions. Females, on the other hand, develop the nodes readily if they inherit the nodal allele from only one parent. If this one parent were the father, he need never have developed nodes if he himself was heterozygous for the nodal allele. If one adds to this constellation the age distribution in our sample, it is not surprising that Heberden's nodes in males are as rare in our sample as in the general population; while female relatives of male, but not of female, non-nodal probands showed an excess of Heberden's nodes, a difference by no means favoured by the age distribution. It would seem likely that environmental factors play an important role in bringing out any hereditary disposition for Heberden's nodes in males; this is a point on which Stecher has not been explicit.

As an example of an environmental cause for Heberden's nodes, their high prevalence in cotton workers may be noted (Lawrence, 1961), but the findings in the female relatives of the male nodal probands would not support the theory that Heberden's nodes due only to environmental influence are frequent in males suffering from multiple osteo-arthrosis.

In no instance did S.C.A.T.-negative polyarthritis occur in both spouses in the population sample of Leigh and Wensleydale, which included 1,200 married persons. The prevalence of S.C.A.T.negative polyarthritis in this population sample was 2.9 per cent. or one in 34 , so that by chance both spouses would be expected to be affected one in $34^{2}=1,220$ matings. Thus it is unlikely that environment, at least in adult life, is responsible for this familial aggregation. An environmental factor in childhood cannot of course be excluded with certainty, nor can the mode of inheritance of the non-nodal type(s) of multiple osteo-arthrosis be determined definitely from this survey in view of the small size of the sample. 


\begin{tabular}{|c|c|c|c|c|c|c|c|c|c|c|c|c|c|c|c|}
\hline \multirow{4}{*}{$\begin{array}{c}\text { Not } \\
\text { Tested }\end{array}$} & & & & & \multicolumn{11}{|c|}{ Female } \\
\hline & \multicolumn{4}{|c|}{ Per cent. of Total Tested } & \multicolumn{7}{|c|}{ Number } & \multicolumn{4}{|c|}{ Per cent. of Total Tested } \\
\hline & \multicolumn{2}{|c|}{+21 and More } & \multicolumn{2}{|c|}{+61 and More } & \multirow{2}{*}{$\begin{array}{l}-61 \\
\text { and } \\
\text { Less }\end{array}$} & \multirow{2}{*}{$\begin{array}{c}-21 \\
\text { to } \\
-60\end{array}$} & \multirow{2}{*}{$\begin{array}{r}-20 \\
\text { to } \\
+20 \\
\end{array}$} & \multirow{2}{*}{$\begin{array}{c}+21 \\
\text { to } \\
+60 \\
\end{array}$} & \multirow{2}{*}{$\begin{array}{l}+61 \\
\text { and } \\
\text { More }\end{array}$} & \multirow{2}{*}{$\begin{array}{c}\text { Total } \\
\text { Tested }\end{array}$} & \multirow{2}{*}{$\begin{array}{c}\text { Not } \\
\text { Tested }\end{array}$} & \multicolumn{2}{|c|}{+21 and More } & \multicolumn{2}{|c|}{+61 and More } \\
\hline & Obs. & Exp. & Obs. & Exp. & & & & & & & & Obs. & Exp. & Obs. & Exp. \\
\hline $\begin{array}{l}2 \\
1\end{array}$ & $\begin{array}{l}69+ \\
44^{*}\end{array}$ & $\begin{array}{l}23 \\
23\end{array}$ & $\begin{array}{r}23 \\
9\end{array}$ & $\begin{array}{l}9 \\
9\end{array}$ & 二 & $\begin{array}{l}4 \\
7\end{array}$ & $\begin{array}{l}9 \\
9\end{array}$ & $\begin{array}{l}4 \\
3\end{array}$ & $\begin{array}{l}1 \\
1\end{array}$ & $\begin{array}{l}18 \\
20\end{array}$ & $\begin{array}{l}1 \\
3\end{array}$ & $\begin{array}{l}28 \\
20\end{array}$ & $\begin{array}{l}30 \\
30\end{array}$ & $\begin{array}{l}6 \\
5\end{array}$ & $\begin{array}{l}8 \\
9\end{array}$ \\
\hline 3 & $58+$ & 23 & 14 & 9 & - & 11 & 18 & 7 & 2 & 38 & 4 & 24 & 30 & 5 & 8 \\
\hline$\overline{2}$ & $\begin{array}{l}40 \\
21\end{array}$ & $\begin{array}{l}29 \\
29\end{array}$ & $\begin{array}{l}15 \\
13\end{array}$ & $\begin{array}{l}7 \\
8\end{array}$ & $\begin{array}{l}1 \\
1\end{array}$ & $\begin{array}{l}3 \\
6\end{array}$ & $\begin{array}{r}12 \\
8\end{array}$ & $\begin{array}{l}3 \\
5\end{array}$ & $\begin{array}{l}2 \\
5\end{array}$ & $\begin{array}{l}21 \\
25\end{array}$ & $\begin{array}{l}3 \\
6\end{array}$ & $\begin{array}{l}24 \\
40\end{array}$ & $\begin{array}{l}34 \\
33\end{array}$ & $\begin{array}{l}10 \\
20\end{array}$ & $\begin{array}{l}12 \\
13\end{array}$ \\
\hline 2 & 30 & 29 & 14 & 8 & 2 & 9 & 20 & 8 & 7 & 46 & 9 & 33 & 33 & 15 & 13 \\
\hline $\begin{array}{l}2 \\
3\end{array}$ & $\begin{array}{l}52 \dagger \\
32\end{array}$ & $\begin{array}{l}27 \\
26\end{array}$ & $\begin{array}{l}18 \\
11\end{array}$ & $\begin{array}{l}8 \\
9\end{array}$ & 1 & $\begin{array}{r}7 \\
13\end{array}$ & $\begin{array}{l}21 \\
17\end{array}$ & $\begin{array}{l}7 \\
8\end{array}$ & $\begin{array}{l}3 \\
6\end{array}$ & $\begin{array}{l}39 \\
45\end{array}$ & $\begin{array}{l}4 \\
9\end{array}$ & $\begin{array}{l}26 \\
31\end{array}$ & $\begin{array}{l}32 \\
32\end{array}$ & $\begin{array}{r}8 \\
13\end{array}$ & $\begin{array}{l}10 \\
11\end{array}$ \\
\hline 5 & $41^{*}$ & 26 & 14 & 9 & 2 & 20 & 38 & 15 & 9 & 84 & 13 & 29 & 32 & 11 & 11 \\
\hline
\end{tabular}

\section{Summary}

The first-degree relatives of twenty males and 32 females with definite osteo-arthrosis in six or more groups of joints, a total of 84 male and 97 female relatives, have been examined clinically, radiologically, and by means of the sheep cell agglutination test (S.C.A.T.) and the test for serum cholesterol, and have been compared with a random sample of the population examined in the same way and at the same time. Altogether 45 of the male and 55 of the female relatives were aged 45 and over and, unless otherwise stated, the following comments refer to this part of the sample, since the findings in the younger relatives did not seem to be remarkable with regard to the characteristics under review.

Definite multiple osteo-arthrosis (five or more groups of joints involved) was found in 36 per cent. of the male relatives, compared with an expected rate of 17 per cent., and in 49 per cent. of the female relatives, compared with an expected rate of 26 per cent.

When the relatives were divided into two groups according to the presence or absence of Heberden's nodes in the proband, definite multiple osteoarthrosis was equally prevalent in both groups, but there was a distinctly higher prevalence of severe multiple osteo-arthrosis (Grade 3 and 4 in at least three groups of joints) in the relatives of the "nodal" probands.

Clinically-observed Heberden's nodes of moderate or severe grade were found in 45 per cent. of female relatives of "nodal" probands (only 10 per cent. expected), and in 13 per cent. of female relatives of "non-nodal" probands (10 per cent. expected).
Clinical inflammatory polyarthritis was present in 38 per cent. of female relatives of "non-nodal" probands but in only 10 per cent. of female relatives of "nodal" probands, the expected rates being 8 and 10 per cent. respectively.

Radiological evidence of erosive arthritis was difficult to assess in this sample, but appeared to be more frequent in the female relatives of non-nodal probands. Morning stiffness also showed a slight increase over the expected rates in this sub-group.

The results of the S.C.A.T. showed no appreciable difference from the expected rates in any group of relatives.

Serum cholesterol showed at least moderate deviations from the appropriate population mean in 58 per cent. of the male relatives under 45 years of age (compared with an expected 23 per cent.), and in 52 per cent. of male relatives, irrespective of age, belonging to "non-nodal" probands (compared with an expected 27 per cent.). In view of the many factors influencing the level of serum cholesterol, no conclusions are drawn from these findings.

Spouses showed no increase in multiple osteoarthrosis over the expected rates.

It is concluded that more than one common inherited factor may give rise to multiple osteoarthrosis. The more severe forms appear to be more closely associated with Heberden's nodes, the others with inflammatory-preponderantly seronegative-polyarthritis.

We wish to express our thanks to Mr. D. Downham for assessing the exact statistical significance of our findings and to Dr. J. Ball for permission to use the results of his sheep cell agglutination tests. 


\section{REFERENCES}

Adams, R. (1857). "A Treatise on Rheumatic Gout." Churchill, London.

Bremner, J. M. (1961). Ann. rheum. Dis., 20, 149.

Cecil, R. L., and Archer, B. H. (1926). J. Amer. med. Ass., 87, 741.

Charcot, J. M. (1881). "Clinical Lectures on Senile and Chronic Diseases", trans. W. S. Tuke. New Sydenham Society, London.

Diem, K., ed. (1962). "Documenta Geigy Scientific Tables", 6th ed. Geigy Pharmaceutical, Manchester.

Downham, D., and McKay, J. Computer J. (In preparation.)

Kellgren, J. H., and Lawrence, J. S. (1956). Ann. rheum. Dis., 15, 1.

- - (1958). Ibid., 17, 388.

- and Moore, R. (1952). Brit. med. J., 1, 181.

Lawrence, J. S. (1961). Brit. J. industr. Med., 18, 270.

_ and Ball, J. (1958). Ann. rheum. Dis., 17, 160.

- and Bennett, P. H. (1960). Ibid., 19, 20.

London, M. G., Muirden, K. D., and Hewitt, J. V. (1963). Brit. med. J., 1, 1380.

Mainland, D., Herrera, L., and Sutcliffe, M. I. (1956). "Statistical Tables for Use with Binomial Samples." Dept. of Medical Statistics, New York University College of Medicine.

Silberberg, M., and Silberberg, R. (1955). J. Bone Jt Surg., 37A, 537.

Sokoloff, L., Crittenden, L. B., Yamamoto, R. S., and Jay, G. E., Jr. (1962). Arthr. and Rheum., 5, 531.

-, Mickelsen, O., Silverstein, E., Jay, G. E., Jr., and Yamamoto, R. S. (1960). Amer. J. Physiol., 198, 765.

Stecher, R. M. (1941). Amer. J. med. Sci., 201, 801.

- (1948). Ann. rheum. Dis., 7, 1.

- (1955). Ibid., 14, 1.
Facteurs génétiques dans l'ostéoarthrose généralisée

\section{RÉSUMÉ}

Des parents proches de 20 hommes et 32 femmes atteints d'ostéoarthrose établie dans six ou plus groupes d'articulations, 84 parents et 97 parentes en tout, furent examinés cliniquement et radiologiquement et leur sang fut soumis à la réaction de Waaler-Rose et à la détermination du cholestérol. Un échantillon de la population, pris au hasard, fut examiné de la même manière et en même temps et on obtint ainsi un moyen de comparaison. Parmi les parents examinés il y en eut 45 hommes et 55 femmes âgés de 45 ans ou plus et, à moins d'avis contraire, dans ce qui suit il s'agira de cette partie de la série examinée, étant donné que les résultats chez de plus jeunes révélèrent peu de caractères recherchés dans cette étude.

Une ostéoarthrose multiple établie (cinq ou plus groupes d'articulations affectées) fut trouvée chez $36 \%$ des parents, mais seulement chez $17 \%$ des témoins et chez $49 \%$ des parentes (témoins femmes: $26 \%$ ).

Lorsqu'on divisa les parents en deux groupes selon la présence ou l'absence de nodosités d'Heberden chez le malade original, la fréquence de l'ostéoarthrose multiple établie fut égale dans les deux groupes, mais l'ostéarthrose multiple grave (grade 3 et 4 dans trois groupes d'articulations au moins) fut nettement plus fréquente chez des parents des malades "noueux".

Des nodosités d'Heberden sévères ou modérés furent trouvées en $45 \%$ des parentes des malades "noueux" (norme: $10 \%$ ) et en $13 \%$ des parentes des malades "non-noueux" (norme: 10\%).

La polyarthrite inflammatoire clinique fut présente en $38 \%$ des parentes des malades "non-noueux", mais seulement en $10 \%$ des parentes des malades "noueux" (norme: $8 \%$ et $10 \%$ respectivement).

L'évaluation des signes radiologiques de l'arthrite érosive fut difficile dans cet échantillon, mais ils semblaient être plus fréquents chez des parentes des malades "non-noueux". Parmi les mêmes parentes l'enraidissement matinal était aussi un peu plus fréquent.

AGE DISTRIBUTION AND RELATIONSHIP ${ }^{2}$ OF RELATIVES

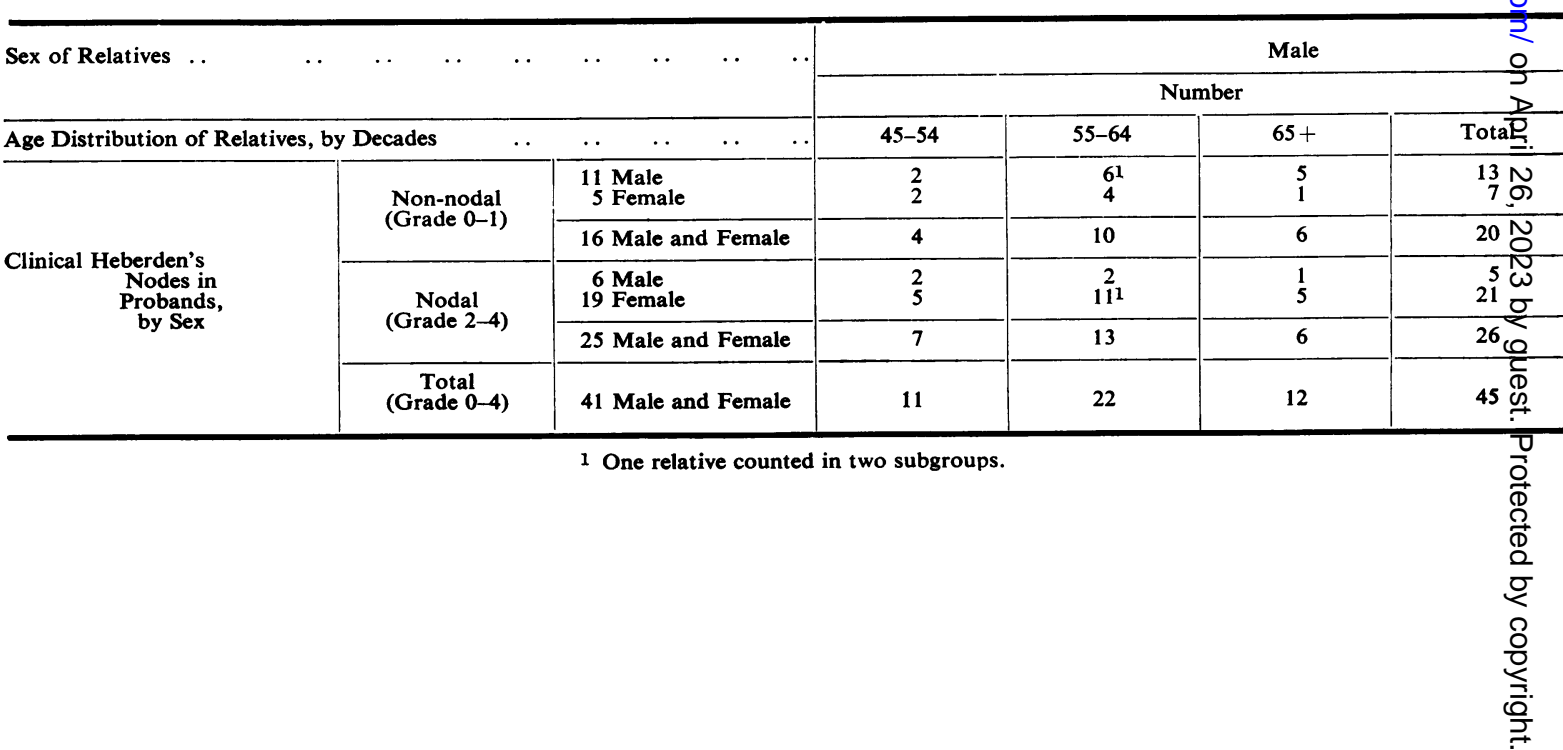


Les résultats de la réaction d'agglutination des érythrocytes de mouton n'accusèrent de déviation appréciable de la norme dans aucun groupe de parents.

Le cholestérol sérique accusa des déviations, au moins modérées, de la moyenne normale en $58 \%$ des parents âgés de moins de 45 ans (norme: $23 \%$ ) et en $52 \%$ de tous les parents mâles de tout âge des malades "nonnoueux" (norme: 27\%). En raison du nombre des facteurs qui influencent le taux du cholestérol, on ne tire pas de conclusions de ces faits.

Les époux n'accusèrent pas d'augmentation de l'ostéoarthrose multiple par rapport à la normale.

On conclut qu'il y a plus d'un facteur héréditaire commun capable d'engendrer l'ostéoarthrose multiple. De plus sévères formes semblent être associées plus intimement aux nodosités d'Heberden, tandis que les autres sont liées à la polyarthrite inflammatoire à prépondérance séro-négative.

\section{Factores genéticos en osteoartrosis generalizada}

\section{SUMARIO}

Los consanguíneos de 20 hombres y 32 mujeres con osteoartrosis probada en seis o más grupos de articulaciones, un total de 84 hombres y 97 mujeres, fueron examinados clínica y radiológicamente, y su sangre fué sometida a la reacción de Waaler-Rose y a la determinación del colesterol. Una muestra de la población, escogida al azar, fué investigada de la misma manera y al mismo tiempo, creándose así una norma de comparación. Entre los consanguíneos examinados 45 hombres y 55 mujeres sobrepasaban la edad de 44 años $y$, a menos que se especifique al contrario, los comentarios que siguen se refieren a esta parte de la serie, ya que los hallazgos en los consanguíneos más jóvenes no parecieron revelar las características buscadas en este trabajo.

Osteoartrosis multiple probada (cinco o más grupos de articulaciones afectas) fué encontrada en un $36 \%$ de los consanguíneos pero sólo en un $17 \%$ de los testigos, y en un $49 \%$ de las consanguíneas (testigos: $26 \%$ ).

Al dividir los consanguíneos en dos grupos, según la presencia o ausencia de nódulos de Heberden en el enfermo determinante, la frecuencia de la osteoartrosis multiple probada fué igual en ambos grupos, pero la osteoartrosis multiple grave (grado 3 y 4 en al menos tres grupos de articulaciones) fué claramente más frecuente en los consanguíneos de enfermos "nodosos".

Nódulos de Heberden graves o moderados fueron encontrados en un $45 \%$ de los consanguíneos de los enfermos "nodosos" (norma $10 \%$ ) y en un $13 \%$ de las consanguíneas de los enfermos sin nódulos (norma: 10).

Poliartritis infamatoria clínica fué presente en un $38 \%$ de las consanguíneas de los enfermos sin nódulos, pero solamente en un $10 \%$ de las consanguíneas de enfermos con nódulos (norma: $8 \%$ y $10 \%$ respectivamente).

La valoración de los datos radiológicos de la artritis erosiva resultó dificil en esta serie, pero su frecuencia pareció ser mayor en las consanguíneas de los enfermos sin nódulos. En las mismas consanguíneas la rigidez matinal fué también algo más frecuente.

Los resultados de la reacción de Waaler-Rose no acusaron deviación apreciable de la norma en ningún grupo de consanguíneos.

La colesterinemia acusó deviaciones, por lo menos moderadas, de la media normal en $85 \%$ de los consanguíneos de menos de 45 años de edad (norma: $23 \%$ ) y en un $52 \%$ de todos los consanguíneos, sin distinción de edad, de los enfermos sin nódulos (norma $27 \%$ ). En vista de los muchos factores que juegan un papel en el nivel del colestérol sérico, no se saca ninguna conclusión de estos hechos.

Conyugues no acusaron aumento de la incidencia de osteoartrosis multiple sobre la norma.

Se concluye que hay más de un factor hereditario común capaz de originar la osteoartrosis multiple. Formas más graves parecer estar estrechamente asociadas con nódulos de Heberden, mientras que las demás tienden a ligarse con poliartritis inflamatoria predominantemente seronegativa.

\begin{tabular}{|c|c|c|c|c|c|c|c|}
\hline \multirow{3}{*}{$\frac{\text { Per cent. of Total }}{65+}$} & \multicolumn{5}{|c|}{ Female } & \multicolumn{2}{|c|}{ Both Sexes } \\
\hline & \multicolumn{4}{|c|}{ Number } & Per cent. of Total & \multirow{2}{*}{$\begin{array}{l}\text { Total } \\
\text { No. }\end{array}$} & \multirow{2}{*}{$\frac{\text { Per cent. of Total }}{65+}$} \\
\hline & $45-64$ & $55-64$ & $65+$ & Total & $65+$ & & \\
\hline $\begin{array}{l}39 \\
14\end{array}$ & $\begin{array}{l}7^{*} \\
2\end{array}$ & $\begin{array}{l}3 \\
3\end{array}$ & $\begin{array}{l}4 \\
5 \dagger\end{array}$ & $\begin{array}{l}14 \\
10\end{array}$ & $\begin{array}{l}29 \\
50\end{array}$ & $\begin{array}{l}27 \\
17\end{array}$ & $\begin{array}{l}32 \\
35\end{array}$ \\
\hline 30 & 9 & 6 & 9 & 24 & 38 & 44 & 34 \\
\hline $\begin{array}{l}20 \\
24\end{array}$ & $\begin{array}{l}2 \\
6\end{array}$ & $\begin{array}{l}5 \\
7\end{array}$ & $\overline{11}+$ & $\begin{array}{r}7 \\
24\end{array}$ & $\begin{array}{r}0 \\
46\end{array}$ & $\begin{array}{l}12 \\
45\end{array}$ & $\begin{array}{r}8 \\
36\end{array}$ \\
\hline 23 & 8 & 12 & 11 & 31 & 36 & 57 & 30 \\
\hline 27 & 17 & 18 & 20 & 55 & 36 & 100 & 32 \\
\hline
\end{tabular}

2 All relatives are siblings, except * including one offspring and + each including one parent. 